\title{
Fen Bilimleri Öğretmenlerinin eTwinning Proje Süreçlerindeki Deneyimlerine Yönelik Görüşleri
}

\section{Ragıp Çavuş ${ }^{1} \quad$ Muhammed Doğukan Balçın² Muhammet Mustafa Yılmaz $^{2}$}

Type/Tür:

Research/Araştırma

Received/Geliş Tarihi: April 5/

5 Nisan 2020

Accepted/Kabul Tarihi: August

19/19 Haziran 2020

Page numbers/Sayfa No: $246-272$

Corresponding

Author/Iletişimden Sorumlu

Yazar: ragipcavus@hotmail.com

\section{$\checkmark$ iThenticate}

This paper was checked for plagiarism using iThenticate during the preview process and before publication. / Bu çalışma ön inceleme sürecinde ve yayımlanmadan önce iThenticate yazılımı ile taranmıştır.

Copyright $\odot 2021$ by Cumhuriyet University, Faculty of Education. All rights reserved.

\begin{abstract}
Öz
$\mathrm{Bu}$ çalışmada eTwinning projesine katılan fen bilimleri öğretmenlerinin süreç içerisindeki deneyimlerine yönelik görüşleri incelenmiştir. Araştırma nitel araştırma yöntemine göre tasarlanmış fenomenolojik bir çalışmadır. Araştırmanın çalışma grubunu 20182019 eğitim-öğretim yılında farklı illerde görev yapan 11 fen bilimleri öğretmeni oluşturmaktadır. Çalışma grubundaki öğretmenler, eTwinning platformu üzerinden gerçekleştirilen astronomi içerikli konuların etkinlik temelli öğretilmesine yönelik hazırlanan proje çalışmasına katılım sağlamıştır. Beş haftalık süreç içerisinde öğretmenler, eTwinning platformu üzerinde yer alan proje ile ilgili etkinlikleri sınıflarında gerçekleştirmiş olup etkinliklere ait görüşlerini ve görselleri projeye katılan diğer meslektaşları ile paylaşmışlardır. Sürecin sonunda öğretmenler öğrencilerinin gerçekleştirdikleri etkinlikleri ve oluşturdukları ürünleri kendi okullarında sunmaları amacıyla bir sergi gerçekleştirmiş ve proje tamamlanmıştır. Veri toplama aracı olarak açık uçlu soru formu kullanılmıştır. Verilerin analizinde içerik analizi kullanılmıştır. Elde edilen bulgular öğretmenlerin görüşleri ile desteklenmiştir. Araştırmanın sonucunda öğretmenlerin bu proje çalışmalarına etkinlik temelli ders işlemek ve mesleki gelişimlerine katkı sağlamak amacıyla katıldıkları belirlenmiştir. Öte yandan gerçekleştirilen etkinliklerin öğrencilerde merak uyandırdığı, öğrencilerin sürece aktif katıldıkları, soyut olan kavramları eğlenerek öğrendikleri ve somutlaştırdıkları da elde edilen sonuçlardandır. Öğretmenler proje ile ilgili ayrılan sürenin daha uzun olması, daha fazla etkinliğe yer verilmesi ve süreçte meslektaşları arasındaki iletişimin daha güçlü olması gerektiği gibi önerilerde bulunmuşlardır.
\end{abstract}

Anahtar Kelimeler: Fen bilimleri, eTwinning projesi, etkinlik temelli öğretim, ortaokul öğrencileri

\footnotetext{
Suggested APA Citation/Önerilen APA Atıf Biçimi:

Çavuş, R., Balçın, M. D. \& Yılmaz, M. M. (2021). Fen bilimleri öğretmenlerinin etwinning proje süreçlerindeki deneyimlerine yönelik görüşleri. Cumhuriyet International Journal of Education, 10(1), 246-272. http://dx.doi.org/10.30703/cije.714843
}

\footnotetext{
${ }^{1}$ Doktora Öğrencisi, Sakarya Üniversitesi, Eğitim Bilimleri Enstitüsü, Sakarya/Türkiye PhD Student, Sakarya University, Institute of Educational Sciences, Sakarya/Turkey e-mail: ragipcavus@hotmail.com ORCID ID: orcid.org/0000-0003-3449-5729

2 Doktora Öğrencisi, Marmara Üniversitesi, Eğitim Bilimleri Enstitüsü, İstanbul/Türkiye PhD Student, Marmara University, Institute of Educational Sciences, İstanbul/Turkey e-mail: dogukanbalcin@gmail.com ORCID ID: orcid.org/0000-0002-7698-6932

3 Öğretmen, Millî Eğitim Bakanlığı, Balıkesir/Türkiye

Teacher, Ministry of National Education, Balıkesir/Turkey e-mail: m.mustafayilmaz@hotmail.com ORCID ID: orcid.org/0000-0002-8605-1380
} 


\title{
The Opinions of Science Teachers about Their Experiences in eTwinning Project Processes
}

\begin{abstract}
In the research, opinions of science teachers who participated in eTwinning projects about experiences in the process were examined. This research adopts a phenomenological study design in accordance with qualitative research method. The study group of the current research consists of 11 science teachers who worked in different cities of Turkey in the 2018-2019 academic year. The teachers in the study group were asked to participate in the project study that was prepared for the activity-based teaching of astronomy topics carried out through the eTwinning platform. Within the five-week period, teachers carried out the activities related to the project in the eTwinning platform in their classrooms, and they shared their opinions and visuals about the activities with other colleagues that participated in the project. At the end of the process, the project was completed when teachers organized an exhibition in order to present their students' activities and the products created at their schools. As the data collection tool, open ended question form was used. The content analysis was used in the analysis of data. The data obtained were supported via opinions of teachers. As a result of the research, it was determined that teachers participated in these project studies in order to teach activity-based courses and contribute to their professional development. On the other hand, it is also a result of the activities that made the students raise curiosity; therefore, they actively participated in the process, learned by having fun and embodied abstract concepts. The teachers made suggestions such as longer time needed for the project and more activities should be involved and the communication should be stronger between colleagues in the process.
\end{abstract}

Keywords: Science, eTwinning project, activity-based teaching, secondary school students

\section{Giris}

Teknolojinin gelişmesi ile küreselleşen dünyada bilgiden daha fazla yararlanma gereksinimi duyulmaya başlanmıştır. Bu durum bilgiye ulaşma teknolojilerinin gelişimini beraberinde getirmiştir. Böylece günümüzde bilgi ve iletişim teknolojileri yoğun olarak kullanılmaya başlanmış ve bilginin dolaşımı hızlanmıştır. Teknoloji alanında yaşanan bu değişimler hayatın her alanına yansımıştır. Var olan bilginin, teknolojinin, gereksinim duyulan insan gücünün sürekli değişime uğramasıyla yaşanan gelişmelerden en çok etkilenen kurumlardan biri de hiç kuşkusuz farklı sektörlere insan gücü yetiştiren eğitim kurumlarıdır (Gülcü, Solak, Aydın ve Koçak, 2013). Eğitim alanının teknolojik gelişim ve değişimlerden önemli derecede etkilenmesi eğitim kurumlarının da yapı ve işlevlerinde farklılaşmaya neden olmuştur. Günümüzde eğitim ve öğretim faaliyetlerinin desteklenmesi ve kolaylaştırılması amacıyla bilgi ve iletişim teknolojilerinin kullanımının her geçen gün yaygınlaşmaya başlaması (Pekdağ, 2005) bu durumun bir kanıtı olarak görülebilmektedir. Genç nüfusun eğitim-öğretim faaliyetleri içerisinde yeni teknolojiler ile tanışması, ülkelerin gelişimine olumlu yönde yansımaktadır (Aksoy, 2003). Buna bağlı olarak bireyler, öğrenme süreçlerinde daha aktif oldukları bir rol üstlenmeye başlamıştır. Dolayısıyla artık eğitim-öğretim faaliyetleri, öğretmenin merkezde aktaran olduğu bir şekilde değil fiziksel ortamlara bağlı olmayan bir hal almaya başlamıştır (Tuncer ve Taşpınar, 2007). Bu durumun ortaya çıkmasında kuşkusuz bilgi ve iletişim teknolojilerinin kullanımının yaygınlaşması ve bu teknolojileri kullanan yaş grubunun giderek küçülmesi etkili olmuştur. Yaşadığımız 
bilişim çağında bilgiye hızlı erişim bireylerin gelişmesi ve bazı becerilere sahip olması adına hayati önem taşımaktadır (Çetin, Çakıroğlu, Bayılmış ve Ekiz, 2004). 21. yüzyıl becerileri olarak nitelendirdiğimiz beceriler ile bireyin girişimci, yenilikçi, iletişim becerileri kuvvetli, yaratıcı ve eleştirel düşünen, günlük hayat problemlerini çözebilen, bilgi ve iletişim teknolojilerini kullanabilen bir birey haline gelmesi ancak uygulamalı bir eğitimle gerçekleştirilebilir (Yanpar-Yelken, 2009).

Tüm dünyada, eğitim politikacıları 21. yüzyılda sürdürülebilir kalkınmayı sağlamak ve istikrarlı bir temel oluşturmak amacıyla çeşitli eğitim sistemlerini geliştirmek için çalışmaktadır (Papadakis ve Kalogiannakis, 2010). Ülkemizde de son yıllarda değişen ve yenilenen öğretim programlarımızdaki eğitim anlayışına göre bilginin öğrenen tarafından oluşturulması esastır. Yani öğrenci bilgiyi doğrudan alan değil, süreç içerisinde aktif olarak sahip olduğu ön bilgiyi yapılandıran bir bireydir. $\mathrm{Bu}$ durumda sinıflarda, öğretmenin geleneksel, doğrudan aktaran yapisından uzaklaşarak artık öğrenci gibi etkinlikte faaliyet göstermesi beklenmektedir (Açıkgöz, 2002). Böylece eğitim sistemimizdeki anlayışla öğrencinin çok daha aktif olduğu, öğretmenin bilgi aktaran yerine etkinlik üreten öğrencilere yol gösteren olduğu bir eğitim-öğretim ortamı oluşturulmaya çalışılmaktadır. Bu bağlamda öğretmenin rolü yeni etkinlikler üreterek dersi daha çok öğrenci merkezli hale dönüştürmektir (Kyriacou, 1992). Eğitim alanında özellikle son dönemlerde yapılan çalışmalar etkinlik temelli öğrenmenin öneminin arttı̆̆ını göstermektedir (Arı, Çavuş ve Sağlık, 2010; Batd1, 2014; Camci, 2012; Coşkun, 2005; Gürbüz, Çatlığlu, Birgin ve Erdem, 2014; Kösterelioğlu, Bayar ve Akın-Kösterelioğlu, 2014; Küpcü, 2008; Suzuki ve Harnisch, 1995; Uğurel ve Bukova-Güzel, 2010).

Etkinlik temelli öğrenme sürecinde öğrenciler işlenen konu içeriği ve öğretim stili ne kadar zevkli, dikkat çekici ise o kadar öğrenme yaşantılarına aktif bir şekilde katılırlar. Dersleri öğrenci merkezli hale getirmenin en önemli yollarından bir tanesi etkinlik temelli ders işlemektir. Ders sirasında kullanılan etkinliklerin öğrenmenin kalıcı olmasında, derse yönelik olumlu ilgi ve tutumun oluşmasında etkili olduğu düşünülmektedir (Camci, 2012). Etkinlikler öğrenme-öğretme süreci içerisinde soyut kavramları somutlaştırmak ve öğretimi etkili bir hale getirmek amacıyla kullanılmaktadır (Gürbüz vd., 2014). Bunun yanında etkinlikler dersleri tekdüzelikten kurtarmakta ve öğrencileri derste daha etkin kılarak etkili bir sınıf ortamının oluşmasını sağlamaktadır (Kurtdede-Fidan, 2015). Bu nedenle ders işlenişi sırasında öğretim etkinliklerinin kullanılması öğrenme açısından önemlidir.

Dersin işlenişi sırasında kullanılacak etkinliklerin hazırlanması sürecinde bazı noktalara dikkat edilmesi gerekmektedir. Etkinliklerin hazırlanmasında dikkat edilmesi gereken birtakım özellikler şu şekildedir:

- Kavramın anlaşılmasını ortaya koyacak kritik noktalara değinilmeli,

- Görsellik içermeli ve aynı zamanda öğrenenler için anlamlı olmalı,

- Öğrenen bireyin öğrenme sürecinde akran etkileşimi, ön öğrenmeleri ve deneyimleri sayesinde bilgiyi yapılandırması için fırsat tanınmalı,

- Etkinlikler günlük yaşam problemlerini içermeli,

- Öğrenenlerin motivasyonları dinamik tutulmalı,

- Öğrenenler ezberledikleri bilgilerinden uzak tutulmalı ve onlara düşünme, tartışma ve tahmin etme fırsatı verilmelidir (Doolittle, 2014; Ishii, 2003; Saunders, 1992). 
Günümüzde benimsenen eğitim anlayışı gereği öğrenen bireylerin öğrenme süreci içerisinde aktif konumda bulunmaları ve bu süreçte de öğretim materyallerinden yararlanmaları önem taşımaktadır (Yanpar-Yelken, 2009). Bu nedenle öğretmenlerin öğrenme-öğretme sürecinde kullanacakları etkinlikler ve materyaller oluşturmaları mesleki bir gerekliliktir. 2009 yılında Türk Eğitim Derneği (TED) tarafından “Öğretmen Yeterlikleri” özet raporunda bir öğretmenin sahip olması gereken yeterlikler içerisinde etkinlik ve materyal oluşturma becerilerinden ders yürütücüsünün sahip olduğu alan ve pedagoji bilgilerinin yanında geliştirdikleri materyalleri, alana ait öğretilecek içeriğin teknoloji ile bütünleştirilmesine ilişkin bilgi ve beceriye sahip olması gerektiği şeklinde bahsedilmektedir (TED, 2009).

Yenilenen öğretim programlarının uygulamasında öğretmenlerin çeşitli sorunlar yaşadıkları araştırmalarda belirtilmektedir (Aydın, Laçin ve Keskin, 2018; Karacaoğlu ve Acar, 2010). Bu sorunlardan birinin de öğretmenin her ders ve her konu için materyal bulma ya da etkinlik üretme sürecinde güçlük yaşayabilmesidir. Bu durum ise aynı branştaki öğretmenlerin etkinlik oluşturmada iş birliği yapmalarının önemini ortaya koymaktadır. Ancak her öğretmenin sahip olduğu şartlar veya bulundukları konum belirli dönemlerde toplanmalarına imkân vermemektir. Bir materyalin elle hazırlanabildiği gibi bilgisayar temelli de hazırlanabileceğinden (Yanpar-Yelken, 2009) bu durum sanal platformlar kullanılarak aşılabilir. Ülkemizde de sanal ortamda doküman paylaşımının yapılabildiği, toplantıların düzenlenebildiği ve eğitimdeki kaliteyi arttırmaya katkı sağlamak amacıyla kullanılmakta olan birçok platform mevcuttur (Şahin, 2012). Eğitim Bilişim Ağı (EBA), Khan Academy ve eTwinning platformu bunlardan bazılarıdır.

Son yıllarda popülaritesi artan eTwinning, Avrupa Birliği Hayat Boyu Öğrenme Programı kapsamında kurulan, bilgi ve iletişim teknolojileri kullanarak öğretmen, öğrenci ve okul iş birliğini teşvik eden Avrupa'daki okullar topluluğudur (Vuorikari vd., 2011). Hayat boyu öğrenme eyleminin bir parçası olan eTwinning programı, neredeyse Avrupa'nın tamamındaki binlerce okula ulaşmış olup eğitimde çeşitli teorik gerekçelerin, yönetimsel fikirlerin ve pratik çözümlerin buluştuğu kültürel bir platform haline gelmiştir (Gajek, 2012). 2005 yılında Avrupa Komisyonu'nun Öğrenme Programı tarafından başlatılmış olan eTwinning çalışmalarının, 2014 yılından itibaren AB Eğitim, Öğretim, Gençlik ve Spor programı olarak bilinen Erasmus+'a güçlü entegrasyonu sağlanmıştır (AB Eğitim, Öğretim, Gençlik ve Spor Programı, 2020). eTwinning, Avrupa ülkelerindeki katılımcı okullarla iletişim kurabilmek, iş birliği yapabilmek ve projeler geliştirip bu projeleri paylaşmak amacıyla takip edilen bir platformdur. Ayrıca ögretmenler tarafından genellikle projeler üretmek ya da var olan projelere ortak olarak katılmak amaciyla kullanılmaktadır. Bu platform sayesinde öğretmenler yapacakları etkinlikleri tasarlar, başka okuldaki öğretmenlerle ortaklık kurarak etkinlik paylaşımında bulunur ve aynı etkinlik farklı okullarda, farklı öğrencilerle gerçekleştirilir. Projeye katılan her öğretmen öğrencileriyle beraber etkinliklere dahil olur. Aynı zamanda öğretmenler ve öğrenciler, proje ile alakalı etkinliklerin görsellerini paylaşabilir, birbirleriyle iletişime geçebilir ve yapmış oldukları farklı çalışmaları diğer katılımcılara sunabilir (Bozdağ, 2017). Bu süreçte öğrenciler, sınıf ortamında daha etkin bir rol oynar. eTwinning projelerinin vizyonuna bakıldığında farklı kültürler arasında etkileşimle projelerin gerçekleştirildiği görülmektedir. eTwinning'de küresel eğitim ve kültürlerarası 
farkındalığın araştırıldı ̆̆ı çalışmalar da alanyazında yer almaktadır (Camilleri, 2016). Uluslararası alanyazın incelendiğinde eTwinning projesi ile kültürlerarası yeterliğin gelişimi ile ilgili öğrenci algılarının belirlenmesine yönelik yapılmış çalışmalar (Valles, 2017) ve dil öğretiminde eTwinning projelerinin kullanıldı̆̆ı çalışmaların (Akdemir, 2017; Moura, 2014) yer aldığ1 görülmektedir.

Öğretmenler öğrenme-öğretme sürecinin planlamasında ve uygulanmasında üstlendikleri aktif rolü, eTwinning projelerinde de benimsemelidir. Nasıl ki öğretim programlarında hedeflenen becerilerin öğrencilere kazandırılması için öğretmenlerin zengin bir öğrenme ortamı oluşturması ve bazı yeterliklere sahip olması gerekiyorsa eTwinning gibi projelerde de öğretmenlerin büyük sorumlulukları vardır. Öğretmenler sahip oldukları yeterliklerle öğrencilere rehber olacağından proje sürecinde büyük öneme sahiptirler. eTwinning eğitim portalı incelendiğinde portala 818.324 (A ğustos 2020) öğretmenin kayıtlı olduğu görülmektedir (AB Eğitim, Öğretim, Gençlik ve Spor Programı, 2020). Uluslararası alanyazın incelendiğinde özellikle Avrupa'da öğretmenler ile yapılan ve onların görüşlerine başvurulduğu birçok çalışmanın yer aldığ1 görülmektedir (Camilleri, 2016; Crişan, 2013; Fat, 2012; Holmes, 2012; Konstantinidis, 2012; Vuorikari vd., 2011). Ancak ulusal alanyazın incelendiğinde ise öğretmenlerin genel olarak eTwinning projelerinden haberdar olmadıkları ve bilgi sahibi olanların da edindikleri eksik bilgiler nedeniyle proje yürütmekten kaçındıkları anlaşılmaktadır (Buluş-Kırıkkaya ve Yıldırım, 2019). Öte yandan eTwinning projelerinin son yıllarda popüler olmasına rağmen projelerle ilgili öğretmenlerin görüşlerinin incelendiği çalışmaların sayıca yetersiz olduğu görülmektedir. Kampylis, Bocconi ve Punie (2012) tarafından yapılan bir araştırmada eTwinning gibi platformların etkili kullanılmasını ve yaygınlaşmasını engelleyen ve kolaylaştıran faktörlerin incelenmesi gerektiği belirtilmiştir. Ayrıca eTwinning benzeri platformların öğretmenlerin deneyimleri ve bu platformlarla ilgili diğer eğitim paydaşlarının farkındalığı üzerine araştırmalar yapılması gerektiği alanyazında vurgulanmiştır (Kampylis vd., 2012). eTwinning projelerinin farklı dersler kapsamında farklı branşlardaki öğretmenlerce gerçekleştirilebileceği ve bu durumun da öğrenme-öğretme sürecine zenginlik katacağı düşünülmektedir. Bu derslerden biri de fen bilimleri dersidir.

Fen bilimlerinin etkinlik temelli öğretim çerçevesinde materyal desteğiyle işlenmesi gereken derslerden biri olduğu düşünülmektedir. Alanyazına bakıldığında etkinlik temelli öğretim yaklaşımının fen eğitiminde farklı konuların öğretiminde kullanıldı̆̆ı görülmektedir. Bu sayede öğrencilerin bilimsel süreç becerilerinin, fen bilimleri dersi akademik başarılarının, fen bilimlerine yönelik tutumlarının ve derse yönelik motivasyonlarının olumlu yönde gelişim gösterdiği tespit edilmiştir (Başdaş, 2007; Koç ve Böyük, 2012; Sadi ve Çakıroğlu, 2011). Ancak fen bilimleri öğretmenleri ile yürütülen araştırmalarda ders kitaplarındaki etkinliklerin yetersiz olması, sınıfların kalabalık olması, derse ayrılan sürenin yetersiz olması, etkinlik planlamanın ve etkinliklerle öğretim sürecinin aşırı iş yükü oluşturması ve zaman alması ile etkinlikler sırasında sınıf yönetimiyle ilgili problemlerin oluşması gibi nedenlerden dolayı öğretim sürecinde etkinliklere yer vermedikleri ya da daha az sayıda verdikleri belirlenmiştir (Akıncı, Uzun ve Kışoğlu, 2015; Balbağ, Leblebicier, Karaer, Sarıkahya ve Erkan, 2016; Doğan, 2010; Karaman ve Karaman, 2016; Küçüköner, 2011). Benzer şekilde fen bilimleri öğretmenlerinin proje geliştirme ve uygulama sürecinde fikir 
üretme konusunda zorluklarla karşılaştıkları ve bu süreci ek bir iş yükü olarak gördükleri de alanyazında vurgulanmaktadır (Yamiç, 2019). Oysaki fen bilimleri dersi kapsamında öğrencilerin sürece aktif olarak katıldıkları, öznel bilgilerini oluşturma sürecini yaşadıkları, yaparak ve yaşayarak öğrendikleri bir ortamın oluşturulması esastır. Bu anlamda fen bilimleri öğretmenlerinin bu ortamı oluşturabilecek yeterliklere sahip olması gerekmektedir. Proje çalışmalarına oldukça önem verilen fen bilimleri dersinde son zamanlarda etkinlik temelli öğretimin önemli olduğu düşünülen eTwinning projelerinin yürütülmeye başlanmıştır. Bu nedenlerden de anlaşılacağ gibi eTwinning projelerinin yürütülmesi ile öğrencilere rehber olma konusunda öğretmenlerin büyük öneminin olduğu ve onların deneyimleri üzerine araştırılmaların yapılması gerektiği düşünülmektedir. Bu çalışmada da eTwinning proje sürecine katılan fen bilimleri öğretmenlerinin öğrencileriyle birlikte aktif olarak katılım sağladıkları proje süreçlerine ilişkin görüşlerinin açığa çıkarılması amaçlanmıştır.

\section{Yöntem}

Araştırma nitel araştırma yöntemine göre tasarlanmış fenomenolojik bir çalışmadır. Fenomenoloji, olgulardan yola çıkarak bireylerin deneyimlerine odaklanılan tümevarımsal bir araştırma modelidir. Fenomenolojik çalışmalarda bireylerin olgulara ilişkin görüşleri aracılığıyla olaya bakışının derinlemesine incelenmesi ve belirlenmesi amaçlanmaktadır (Ersoy, 2016; Mayring, 2000). Araştırmada bir deneyim olarak eTwinning proje çalışmasına aktif olarak katılan fen bilimleri öğretmenlerinin görüşlerinin detaylı incelenmesine odaklanıldığından fenomenolojinin uygun bir araştırma modeli olduğu söylenebilir.

\section{Çalışma Grubu}

Araştırmada çalışma grubunun belirlenmesinde amaçlı örnekleme yöntemlerinden biri olan ölçüt örnekleme kullanılmıştır. Ölçüt örneklemede önceden belirlenen çeşitli ölçüt veya ölçütleri sağlayan katılımcılar araştırma sürecine dahil edilmektedir (Yıldırım ve Şimşek, 2008). Bu çalışmada da fen bilimleri öğretmeni olma, eTwinning projesinde katılımcı olarak yer alma ve süreç içerisinde belirtilen etkinlikleri gerçekleştirme durumları temel ölçüt olarak kabul edilmiştir. Bu kapsamda araştırmanın çalışma grubunu 2018-2019 eğitim-öğretim yılında farklı illerdeki okullarda görev yapan ve eTwinning projesine ortak olan 11 fen bilimleri öğretmeni oluşturmaktadır. Çalışma grubunda yer alan öğretmenlerin demografik özellikleri Tablo 1'de sunulmuştur.

Tablo 1'de yer alan demografik özellikler incelendiğinde projeye katılım sağlayan öğretmenlerin ağırlıklı olarak kadın (\%73), 21-30 yaş arasında (\%82) ve meslekteki ilk yılları içerisinde (\%55) olduğu görülmektedir. Öte yandan proje sürecine dahil olan fen bilimleri öğretmenlerinin tamamının ortaokulda görev yaptığ1 ve tüm coğrafi bölgelerden projeye katılım sağlandı̆̆ı anlaşılmaktadır. 
Tablo 1.

Çalışma Grubunda Yer Alan Öğretmenlerin Demografik Özellikleri

\begin{tabular}{llcc}
\hline & Demografik Özellikler & Frekans (N) & Yüzde (\%) \\
\hline \multirow{2}{*}{ Cinsiyet } & Kadın & 8 & 72.7 \\
& Erkek & 3 & 27.3 \\
\hline \multirow{2}{*}{ Yaş } & $21-30$ yaş & 9 & 81.8 \\
\multirow{2}{*}{ Mesleki kıdem } & $31-40$ yaş & 2 & 18.2 \\
\hline \multirow{2}{*}{ Görev yapılan kurum türüu } & Ortaokul & 6 & 54.5 \\
& Akdeniz Bölgesi & 5 & 45.5 \\
\hline \multirow{4}{*}{ Görev yapıllan coğrafi bölge } & Güneydoğu Anadolu Bölgesi & 11 & 100.0 \\
& İç Anadolu Bölgesi & 2 & 18.1 \\
& Marmara Bölgesi & 2 & 18.1 \\
& Doğu Anadolu Bölgesi & 2 & 18.1 \\
& Ege Bölgesi & 1 & 18.1 \\
& Karadeniz Bölgesi & 1 & 9.2 \\
Toplam & & 1 & 9.2 \\
\hline
\end{tabular}

\section{Veri Toplama Araçları}

Araştırmada veri toplama aracı olarak açık uçlu soru formu kullanılmıştır. Soru formu araştırmacılar tarafından geliştirilmiş olup uzman görüşü alınması için fen bilgisi eğitimi alanındaki iki uzman tarafından incelenmiştir. Sonrasında araştırmacılar formu nihai haline getirmiş ve veri toplama aracı olarak kullanmıştır. Soru formunda öğretmenlerin demografik özelliklerinin yanı sıra proje sürecine dahil olan öğrencilere ilişkin bilgilere ve öğretmenlerin proje sürecini değerlendirmelerine yönelik 9 açık uçlu soruya yer verilmiştir. Açık uçlu soru formunda yer alan sorularla öğretmenlerin;

- Projeye katılım nedenleri,

- Projeye ilişkin görüşleri,

- Projenin öğrencilere katkısına yönelik görüşleri,

- Öğrencilerinin projeye katılım durumlarına ilişkin görüşleri,

- Öğrencilerin katılımını arttırmaya yönelik yapılabilecek çalışmalarla ilgili görüşleri,

- Proje sürecinde gördükleri eksikliklere ilişkin görüşleri,

- Proje ile ilgili yapılmasını istedikleri değişikliklerle ilgili görüşleri,

- Projeye tekrar katılma istekleri ve

- Projeye ilişkin genel değerlendirmeleri

açığa çıkarılmaya çalışılmıştır. Öğretmenlerin proje, proje süreci, sürecin kendilerine ve öğrencilerine katkısı gibi düşünceleri elektronik ortamda toplanmıştır.

\section{Araştırma Süreci}

Araştırma kapsamında 2018-2019 eğitim-öğretim yılı başında “Gökyüzünün Kâşifleri” isimli bir eTwinning projesi hazırlanmış ve projeye onay alınması ile farklı illerde görev yapmakta olan fen bilimleri öğretmenleri projeye ortak olarak dahil edilmiştir. Araştırmaya katılan öğretmenler, projenin yürütüldüğü 5 haftalık süreç içerisinde 5, 6 ve 7. sınıf fen bilimleri dersi kapsamındaki astronomi içerikli konuların öğretiminde eTwinning projesi kapsamında hazırlanan çeşitli etkinlikleri sınıflarında uygulamıştır. $\mathrm{Bu}$ etkinliklerle astronomi konularının etkin öğretimi, öğretmenlerin yaparak ve 
yaşayarak öğrenmenin gerçekleştiği bir ortam oluşturmaları, alternatif etkinlikler üretmeleri amaçlanmıştır. Bunun yanı sıra öğrencilerin gökyüzünü tanıması, öğrencilerde ilgi, merak ve araştırma isteği uyandırma ve yaparak yaşayarak ögrrendikleri etkinlik temelli bir sınıf ortamı oluşturma da projenin amaçları arasında yer almaktadır. Süreç içerisinde araştırmacılar ve projeye katılan fen bilimleri öğretmenlerince hazırlanan ve sinıflarda uygulanan etkinlikler Şekil 1'de gösterilmiştir.
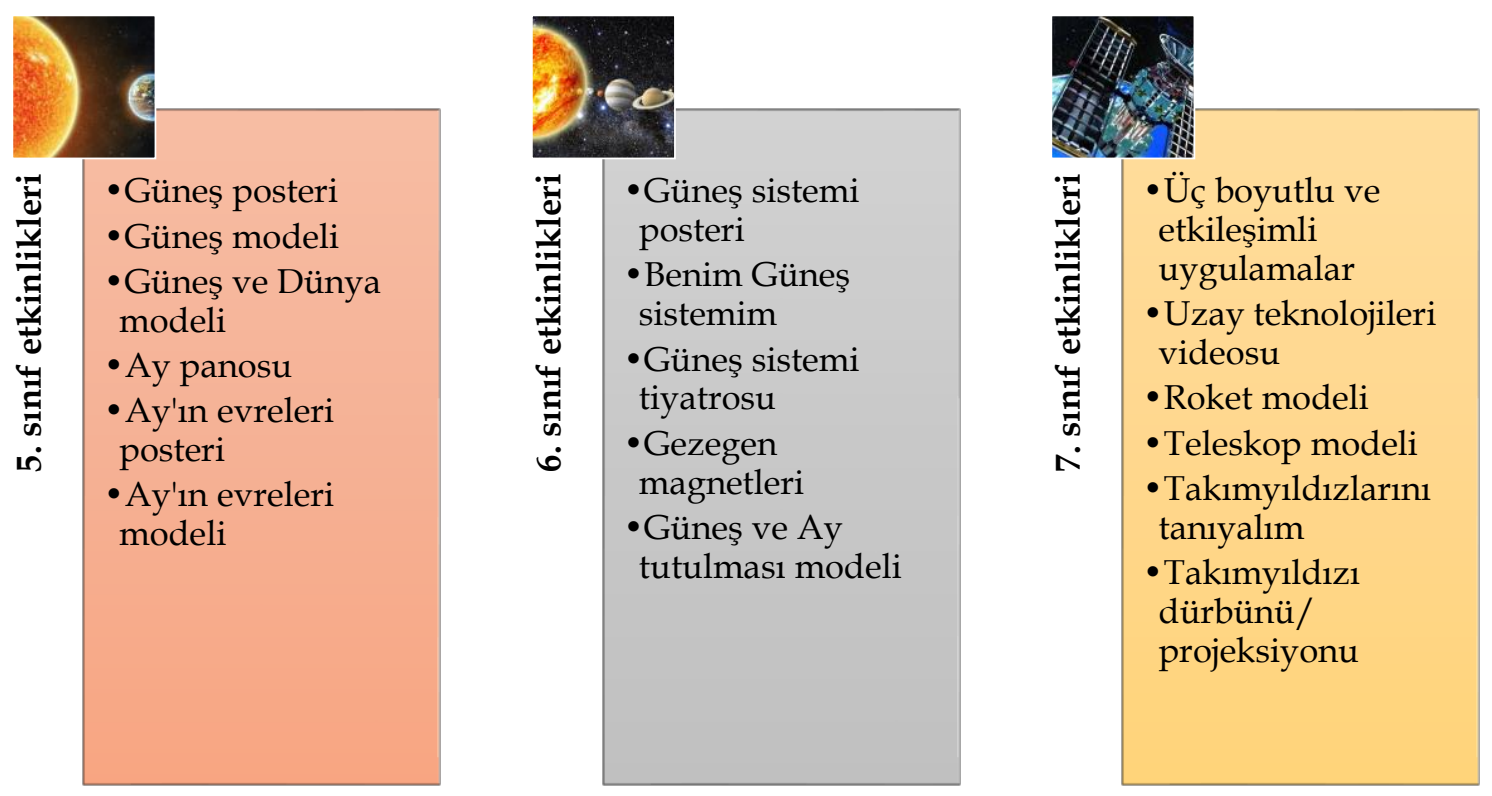

Şekil 1. "Gökyüzünün Kâşifleri” projesinde gerçekleştirilen etkinlikler

Yapılan uygulamaların ardından öğretmenler süreç ve etkinliklerle ilgili çeşitli görselleri, öğrenciler tarafından üretilen çalışmaları ve değerlendirmelerini platform üzerinden diğer katılımcılarla paylaşmıştır. Ünitelerdeki kazanımların ve uygulamaların tamamlanması ile öğretmenler tarafından okullarında sergiler açılmış ve bu sergilerde öğrenciler süreç içerisinde oluşturdukları ürünleri okuldaki arkadaşları ile paylaşma imkânı bulmuştur. Proje sürecine ait görseller Şekil 2'de sunulmuştur.

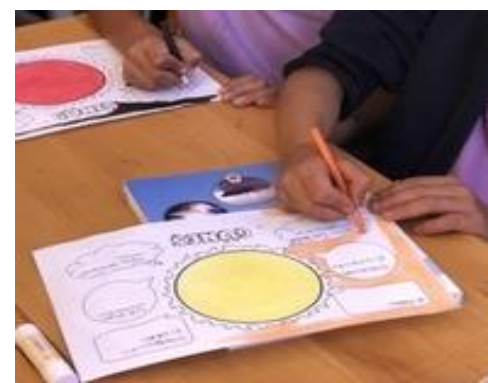

(a) Proje içerisinde yapılan bir etkinlik örneği

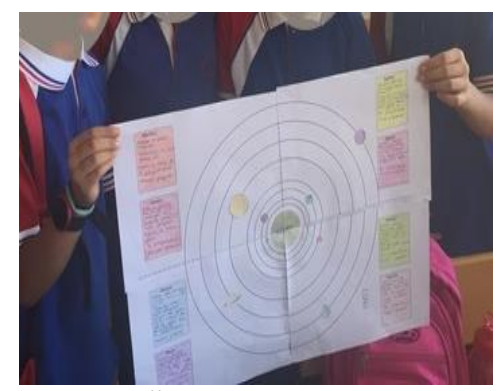

(b) Öğrencilerin proje sürecinde yaptıkları çalışmalar

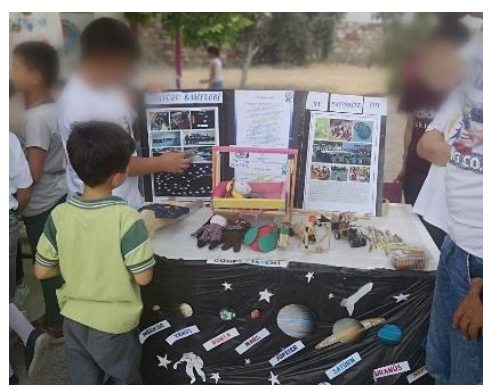

(c) Proje sonunda açılan sergi

Şekil 2. Proje sürecine ait görseller 


\section{Verilerin Analizi}

Katılımcılardan elde edilen bulgular içerik analizi ile değerlendirilmiştir. Veri analizinde yapılandırıcı ve özetleyici içerik analizi kullanılmıştır (Mayring, 2000). Bu kapsamda öğretmenlerin yanıtları incelenmiş ve yanıtlar doğrultusunda araştırmacılar tarafından uygun kategoriler oluşturulmuştur. Öğretmenlerin verdikleri yanttlar birden fazla kategoriye dahil olabileceği için verilere ait sıklık frekansı ve sıklığa bağlı yüzde değerleri de tablolar ve şekiller aracılı̆̆ıla sunulmuştur. Kategorilerde yer alan veriler öğretmenlerin örnek yanıtları ile desteklenmiştir. Öğretmen yanıtları örneklendirilirken katılımcılara Ö1, Ö2, ... Ö11 şeklinde kodlar verilmiştir.

Araştırmanın geçerliği için araştırmaya katılan öğretmenlerle elektronik ortamda yazılı olarak görüşmeler yapılmış ve öğretmenlerin sorulara verdikleri yanıtları teyit etmesi sağlanmış, proje ve araştırma süreciyle ilgili iki fen bilgisi eğitimi alan uzmanının görüşü alınmış, veriler betimlenmiş ve amaca uygun bir örnekleme yöntemi kullanılmıştır.

Araştırmanın güvenirliğini sağlamak için de bulgular üç araştırmacı tarafından birbirinden bağımsız olarak değerlendirilmiş olup, ortak ve farklı kategoriler belirlenmiştir. Araştırmacıların kodlamalarının tutarlı olup olmadığını belirlemek amacıyla kodlayıcılar arasındaki uyum değeri hesaplanmıştır. Araştırma bulgularının değerlendirme aşamasında toplam 45 kategorinin elde edildiği ve bunlardan 40'ının ortak olduğu belirlenmiştir. Kodlayıcılar arasında uyum (güvenirlik) katsayısı da .89 olarak hesaplanmıştır. Miles ve Huberman (1994) güvenirlik katsayısının .80 ve üzerinde olması durumunda çalışmanın güvenirliğinin arttı̆̆ııı belirtmektedir. Farklı kategoriler için araştırmacılar bir araya gelerek kategoriye dahil olabilecek cevapları içerisine alabilecek yeni ortak kategoriler oluşturmuştur. Ardından oluşturulan kategoriler ve kategoriye dahil edilen örnekler fen bilgisi eğitimi alanındaki bir uzman tarafından yeniden incelenmiştir. Benzer şekilde çalışmanın güvenirliğini arttırmak için toplanan verilerden elde edilen bulgular katılımcıların örnek yanıtları ile desteklenerek sunulmuştur.

\section{Bulgular}

Araştırmanın bulguları öğretmenlerin proje çalışmasına katılım nedenleri, projeye ilişkin görüşleri, projenin öğrencilere katkısı, öğrencilerin projeye katılımı, etkinliklere katılımın artırılması için yapılması gerekenler, projenin eksik yanları, proje ile ilgili yapılması istenilen değişiklikler, projeye yeniden katılma istekleri ve projenin genel değerlendirilmesi başlıkları altında sunulmuştur.

\section{Projeye Katılım Nedenleri}

Araştırma kapsamında ilk olarak öğretmenlerin projeye katılım nedenleri incelenmiştir. Öğretmenlerin projeye katılım nedenlerine yönelik soruya verdikleri cevapların analizi Tablo 2'de sunulmuştur. 
Tablo 2

Öğretmenlerin Projeye Katılım Nedenlerine İlişkin Görüşleri

\begin{tabular}{llcc}
\hline \multicolumn{1}{c}{ Kategori } & \multicolumn{1}{c}{ Katılımc1 } & $\begin{array}{c}\text { S1klık frekans1 } \\
\text { (f) }\end{array}$ & $\begin{array}{c}\text { S1klı̆ga bağl1 } \\
\text { yüzde (\%) }\end{array}$ \\
\hline Etkinlik temelli ders işleme & Ö1, Ö5, Ö6, Ö7, Ö11 & 5 & 25.0 \\
Kalıc1 öğrenmeyi sağlama & Ö3, Ö5, Ö9, Ö10 & 4 & 20.0 \\
Eğlenerek öğrenmeyi sağlama & Ö2, Ö3, Ö11 & 3 & 15.0 \\
Mesleki yetkinliği artırma & Ö2, Ö6, Ö11 & 3 & 15.0 \\
Öğrencilerde merak uyandırma & Ö3, Ö9 & 2 & 10.0 \\
Astronomiye ilgi duyma & Ö2 & 1 & 5.0 \\
Bilim insanların tanitma & Ö4 & 1 & 5.0 \\
Üniteye uygun olma & Ö8 & 1 & 5.0 \\
Toplam & & 20 & 100.0 \\
\hline
\end{tabular}

Tablo 2'deki bulgular incelendiğinde öğretmenlerin ağırlıklı olarak etkinlik temelli ders işleme (5 sıklık), kalıcı (4 sıklık) ve eğlenerek ( 3 sıklık) öğrenmeyi sağlama ile mesleki yetkinliklerini artırma ( 3 sıklık) amacıyla bu projeye katılım sağladıkları görülmektedir. Çalışma grubunda yer alan Ö1 kodlu öğretmenin "Derslerimde STEM içerikli etkinlik kullandığım ve etkinlik yönü olduğu için bu projede bulunmak istedim." yantt 'etkinlik temelli ders işleme' kategorisine örnektir. Benzer şekilde Ö9 da uzay konularının derslerde daha iyi anlaşıldığını, öğrencilerde merak uyandırdığını düşündüğünü ve bu nedenle projeye katıldığını belirtmiştir. Ö9'un bu yanıtı da 'öğrencilerde merak uyandırma' kategorisine eklenmiştir. Öte yandan öğretmenler yanıtlarında kalıcı öğrenmeyi sağlama, astronomiyle ilgili olma, bilim insanlarını öğrencilerine tanıtma ve üniteyle uygun olması nedeniyle de projeye katılım sağladıklarını belirtmektedir.

\section{Projeye İlişkin Görüşler}

Öğretmenlere yöneltilen ikinci soruyla projeye ilişkin görüşleri sorgulanmıştır. Öğretmenlerin bu soruya verdikleri yanıtlardan elde edilen kategoriler ve sıklıkları Tablo 3'te yer almaktadir.

Tablo 3

Öğretmenlerin Projeye İlişkin Görüşleri

\begin{tabular}{llcc}
\hline \multicolumn{1}{c}{ Kategori } & \multicolumn{1}{c}{ Katılımc1 } & $\begin{array}{c}\text { S1klık } \\
\text { frekans1 (f) }\end{array}$ & $\begin{array}{c}\text { S1klı̆̆a bağl1 } \\
\text { yüzde (\%) }\end{array}$ \\
\hline Etkinliklerin verimli olmas1 & Ö6, Ö8, Ö9, Ö11 & 4 & 20.9 \\
Eğlenceli öğrenme ortamı oluşturma & Ö2, Ö5, Ö7 & 3 & 15.8 \\
Öğretime yardımci olma & Ö3, Ö5, Ö11 & 3 & 15.8 \\
İlgi çekici olma & Ö1, Ö5 & 2 & 10.5 \\
Planli olma & Ö1, Ö11 & 2 & 10.5 \\
Kavramlar1 somutlaştırma & Ö3 & 1 & 5.3 \\
Kazanımlara uygun olma & Ö3 & 1 & 5.3 \\
Keşfetmeyi sağlama & Ö2 & 1 & 5.3 \\
Öğrenci merkezli olma & Ö3 & 1 & 5.3 \\
Cevapsiz & Ö10 & 1 & 5.3 \\
Toplam & & 19 & 100.0 \\
\hline
\end{tabular}


Öğretmenlerin projeye ilişkin görüşlerini yansıtan Tablo 3 'teki bulgulara bakıldığında öğretmenlerin yanıtlarında çoğunlukla etkinliklerin verimli olduğuna (\%21 sıklıkla), eğlenceli bir öğrenme ortamı oluşturduklarına (\%16 sıklıkla), projenin öğretime yardımcı (\%16 sıklıkla), ilgi çekici (\%11 sıklık) ve planlı (\%11 sıklık) olduğuna vurgu yaptıkları anlaşılmaktadır. Öte yandan öğretmenler, proje sürecindeki etkinliklerin keşfetmeyi ve kavramları somutlaştırmayı sağladığını, kazanımlara uygun ve öğrenci merkezli olduğunu da ifade etmiştir. Ö11 kodlu öğretmenin “Genel olarak iyiydi. Altıncı ve yedinci sinıflarda ilk defa yer alan ünitelerin öğretiminde ve sürecin planlanmasında bana katkı sağladı." yanıtı etkinliklerin verimli olması, öğretime yardımcı olma ve planlı olma kategorilerine dahil edilmiştir. Ö3 de "Proje kazanımlara uygundu. Her kazanımdan sonra yapılan etkinlikler öğrenci odakh olduğu için öğrenme daha kolay gerçekleşti. Astronomi kavramlar öğrencilerimizin gözünde daha somut hâle geldi." yanıtında etkinliklerin öğretime yardımcı olduğunu, kazanımlara uygun olduğunu ve öğrencilerin kavramları somutlaştırmasında etkili olduğunu vurgulamıştır. Araştırmaya katılan öğretmenlerden biri ise soruyu yanıtsız bırakmıştır.

\section{Projenin Öğrencilere Katkısı}

Araştırmada yürütülen projenin öğrencilere katkısının ne olduğu da öğretmenlere sorulmuştur. Öğretmenlerin bu soruya verdikleri cevaplardan yola çıarak elde edilen kategoriler, sıklık frekansları ve yüzde değerleri Şekil 3'teki gibidir.

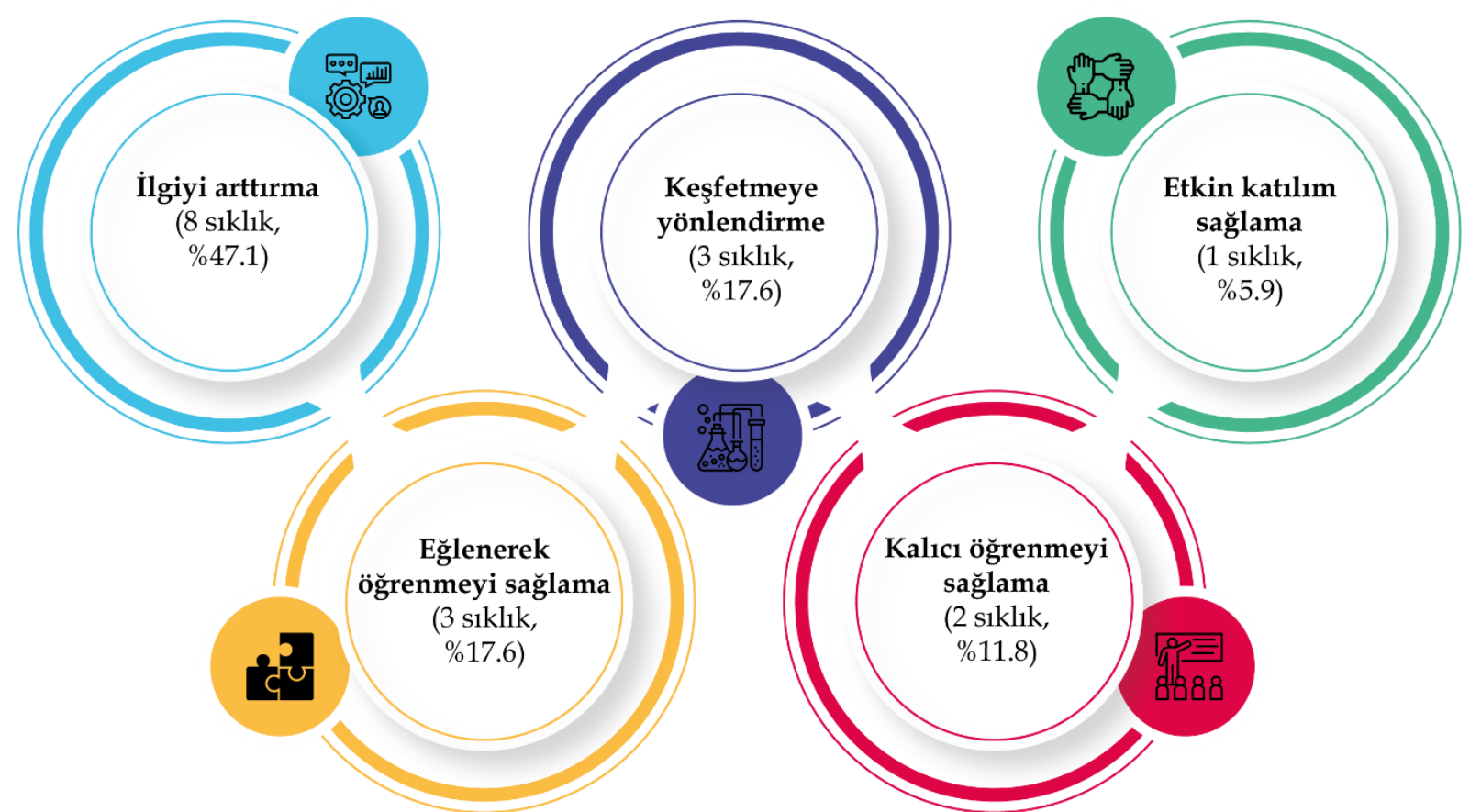

Şekil 3. Öğretmenlerin projenin öğrencilere katkısına ilişkin görüşleri

Çalışma grubunda yer alan öğretmenlerin projenin öğrencilere katkısına ilişkin görüşlerini yansıtan Şekil 3'teki bulgular, öğretmenlerin ağırlıklı olarak proje sürecine katılan öğrencilerinin ilgilerinin arttığını (\%47), eğlenerek öğrendiklerini (\%18) ve keşfetmeye yöneldiklerini (\%18) düşündüklerini göstermektedir. Ö2 kodlu öğretmenin "Öğrencilerim çok ilgiliydi, projedeki etkinlikler de çok keyifli ve öğreticiydi. Verimli bir çalışma gerçekleştirdik." yanıtı projede gerçekleştirilen etkinliklerin öğrencilerin astronomi konularına ve fen bilimleri dersine ilgilerini arttırdığını 
yansıtmaktadır. Ö7 ve Ö9 kodlu öğretmenlerde yanıtlarında öğrencilerinin etkinliklere çok ilgili olduklarını ve etkinlikleri severek yaptıklarını belirtmişlerdir. Ayrıca etkinliklere katılan öğrencilerin kalıcı öğrenmeler sağladıkları ve sürece etkin olarak katıldıkları da öğretmenlerin yanıtlarından elde edilen bulgular arasındadır. Ö1 yanıtında "Sürece çok aktif katılım sağladılar." diyerek projedeki etkinliklerin öğrencilerin sürece etkin katılmalarını sağladığını vurgulamıştır.

\section{Öğrencilerin Projeye Katılımı}

Çalışma grubunda yer alan öğretmenlerin öğrencilerinin projeye katılımına ilişkin görüşlerini yansıtan bulgular Tablo 4'te verilmiştir.

Tablo 4

Öğretmenlerin Öğrencilerin Projeye Katılımına İlişkin Görüşleri

\begin{tabular}{llcc}
\hline Kategori & Katılımcı & S1klık frekansı (f) & S1klığa bağlı yüzde (\%) \\
\hline Katılımda istekli olma & Ö2, Ö3, Ö4, Ö6, Ö7, Ö11 & 6 & 50.0 \\
Etkin katılım sağlama & Ö5, Ö8, Ö9, Ö11 & 4 & 33.3 \\
Görüş belirtmemiş & Ö1, Ö10 & 2 & 16.7 \\
Toplam & & 12 & 100.0 \\
\hline
\end{tabular}

Tablo 4'te yer alan öğrencilerin projeye katılımına ilişkin araştırma grubundaki öğretmenlerin görüşleri incelendiğinde öğretmenlerin ağırlıklı olarak öğrencilerinin projeye katılımda istekli olduklarını (\%50) ve etkin katılım sağladıklarını (\%33) belirttiği anlaşılmaktadır. Ö4'ün "İsteyerek katıldılar. Gökyüzü çok merak ettikleri bir yer." ve Ö6'nın "Öğrenciler etkinlikleri severek ve isteyerek yürüttüler." yanıtları öğrencilerin katılımda istekli olduklarını göstermektedir. Buna ek olarak Ö5 ve Ö8 de yanıtlarında sınıftaki öğrencilerin tamamının etkinliklere katılım sağladığını ve süreç içerisinde aktif olduklarını belirtmişlerdir. Araştırma grubunda yer alan 2 öğretmen ise kendilerine yöneltilen bu soruya görüş belirtmemiştir.

\section{Öğrencilerin Etkinliklere Katılımını Artırmak İçin Yapılabilecek Çalışmalar}

Araştırma kapsamında öğretmenlerin, öğrencilerin etkinliklere katılımını artırmak için yapılabilecek çalışmalara yönelik görüşleri de incelenmiştir. Öğretmenlerin konuyla ilgili kendilerine sorulan sorudan elde edilen bulgular Tablo 5'te sunulmuştur.

Tablo 5

Öğretmenlerin Öğrencilerin Etkinliklere Katılımının Artması İçin Yapılabilecek Çalışmalara İlişkin Görüşleri

\begin{tabular}{llcc}
\hline \multicolumn{1}{c}{ Kategori } & \multicolumn{1}{c}{ Katılımc1 } & $\begin{array}{c}\text { S1klık } \\
\text { frekans1 (f) }\end{array}$ & $\begin{array}{c}\text { S1klığa bağlı } \\
\text { yüzde (\%) }\end{array}$ \\
\hline Etkinliklerin türünü ve sayısını arttırma & Ö2, Ö5, Ö9, Ö10, Ö11 & 5 & 38.5 \\
Projenin süresini arttırma & Ö2, Ö7 & 2 & 15.4 \\
Merak uyandıracak etkinlikler hazırlama & Ö4, Ö10 & 2 & 15.4 \\
İlginç/değişik etkinlikler yapma & Ö1 & 1 & 7.7 \\
Görüş belirtmemiş & Ö3, Ö6, Ö8 & 3 & 23.0 \\
Toplam & & 13 & 100.0 \\
\hline
\end{tabular}


Tablo 5'teki bulgular öğretmenlerin, öğrencilerin etkinliklere katılımının artması için etkinliklerin türünü ve sayısı artırmak gerektiğini (\%39), proje süresinin uzatılması gerektiğini (\%15), merak uyandırmaya yönelik etkinlikler oluşturmak gerektiğini (\%15) ve ilginç etkinliklere yer vermek (\%8) gerektiğini düşündüklerini göstermektedir. Çalışma grubunda yer alan Ö2 kodlu öğretmenin “... Daha fazla etkinlikle proje devam ettirilebilirdi." cevabı öğretmenlerin çoğunlukla etkinliklerin sayısının arttırılmasını isteklerini düşündürmektedir. Öte yandan Ö7 de yanıtında projenin devam ettirilmesinin öğrenciler için yararlı olacağını ifade etmiştir. Ayrıca Ö4 ve Ö10 yanıtlarında projede öğrencilerin ilgisini çekecek daha fazla etkinliğe yer verilmesini istediklerini vurgulamıştır. Araştırmaya katılan 3 öğretmen ise bu soruyu yanıtsız bırakmış ve konuyla ilgili görüş belirtmemiştir.

\section{Projenin Eksik Yanlarına İlişkin Görüşler}

Araştırmada öğretmenlere yöneltilen diğer bir soru ile projenin eksik yanlarına ilişkin görüşleri irdelenmiştir. Öğretmenlerin konuyla ilgili verdikleri yanıtlardan yola çıkılarak elde edilen bulgular Şekil 4'te yer almaktadır.

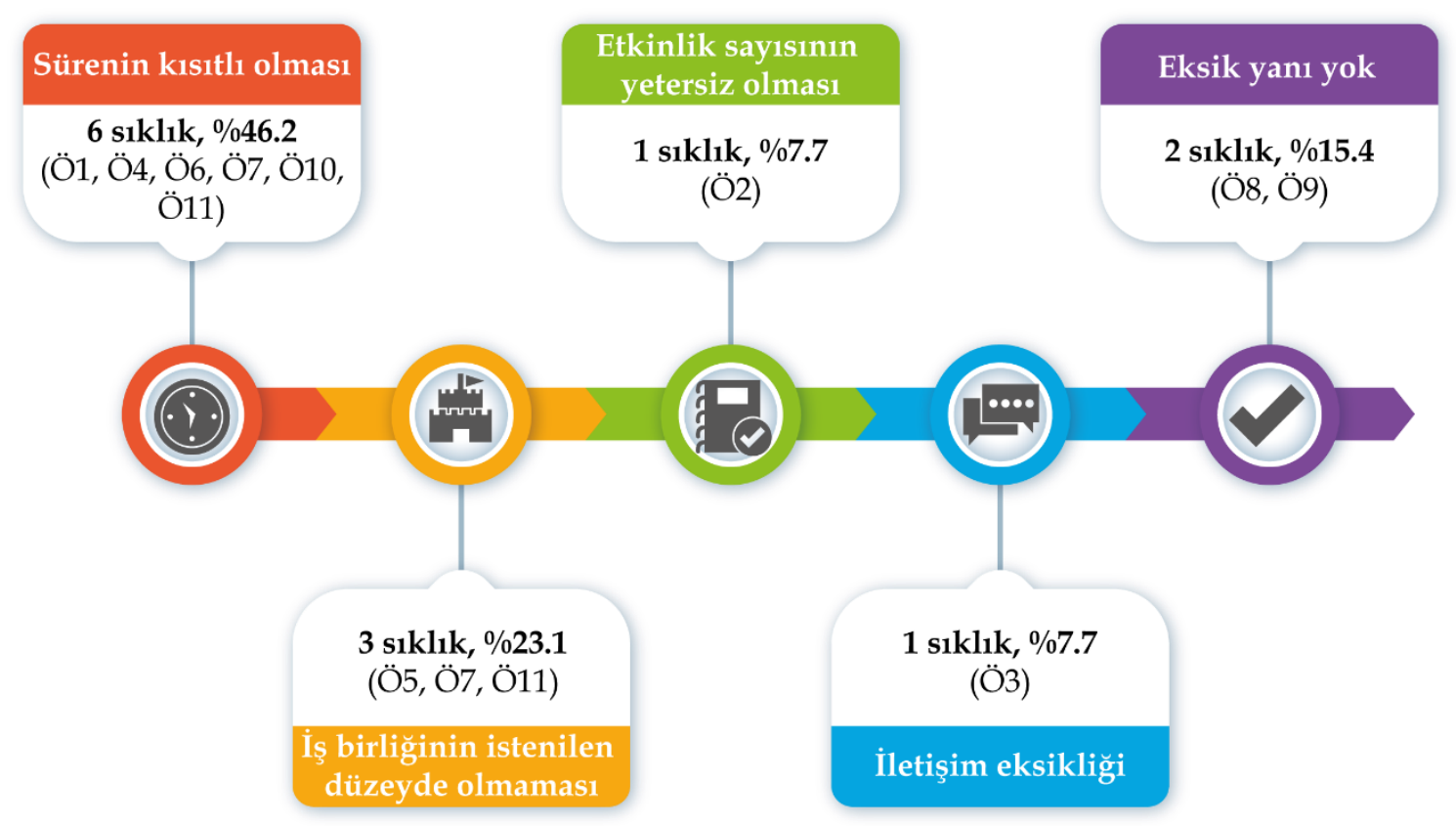

Şekil 4. Öğretmenlerin projenin eksik yanlarına ilişkin görüşleri

Öğretmenlerin projenin eksik yanlarına ilişkin görüşlerinin yer aldığ Şekil 4'teki bulgular, sürenin kısıtlı olduğunu (\%46), katılımcı öğretmenler arasındaki iş birliğinin istenilen düzeyde olmadığını (\%23), etkinliklerin sayıca az olduğunu (\%8), katılımcılar arasında iletişim eksikliğinin olduğunu (\%8) göstermektedir. Bu duruma örnek olarak Ö1, Ö4 ve Ö10 yanıtlarında projenin süresinin yeterli olmadığını ve biraz daha uzun sürmesini istediklerini ifade etmiştir. Ö7'nin "Hemen bitti. Biraz daha etkinlik olsaydı daha güzel olurdu. Diğer arkadaşlarda daha aktif katılım să̆lamış olsaydı projeye beraber devam edebilirdik." yanıtı da hem etkinlikler için ayrılan sürenin uzatılmasını hem de diğer katılımcılarla iş birliğinin arttırılmasını istediğini göstermektedir. Öte yandan çalışma grubunda yer alan 2 öğretmen de projenin eksik bir yanının bulunmadığını (\%15) belirtmiştir. 


\section{Proje ile İlgili Yapılması İstenilen Değişiklikler}

Araştırma kapsamında öğretmenlerin projeyle ilgili yapılmasını istedikleri değişikliklere ait bulgular Tablo 6' da sunulmuştur.

Tablo 6.

Öğretmenlerin Proje ile İlgili Yapılmasını İstedikleri Değişikliklere İlişkin Görüşleri

\begin{tabular}{llcc}
\hline \multicolumn{1}{c}{ Kategori } & \multicolumn{1}{c}{ Katılımc1 } & $\begin{array}{c}\text { Sıklık } \\
\text { frekans1 (f) }\end{array}$ & $\begin{array}{c}\text { Sıklı̆̆a } \\
\text { bağlı } \\
\text { yüzde (\%) }\end{array}$ \\
\hline Etkinlik süresini uzatma & Ö2, Ö4, Ö6, Ö7, Ö10 & 5 & 38.4 \\
Etkinlik sayısını artırma & Ö2, Ö5 & 2 & 15.4 \\
Konuyla ilgili gözlem yapma & Ö5, Ö11 & 2 & 15.4 \\
İletişimi güçlendirme & Ö3 & 1 & 7.7 \\
Teknoloji içerikli etkinliklerin sayısını artırma & Ö1 & 1 & 7.7 \\
Cevapsiz & Ö8, Ö9 & 2 & 15.4 \\
Toplam & & 13 & 100.0 \\
\hline
\end{tabular}

Tablo 6' daki bulgular incelendiğinde öğretmenlerin projeyle ilgili yapılmasını istedikleri değişikliklerin başında etkinlik süresinin uzatılmasının (\%39), etkinlik sayısının artırılmasının (\%15) ve konuyla ilgili öğrencilerin gözlem yapabilmesinin (\%15) geldiği görülmektedir. Ö2'nin "Etkinlik sayısı arttırllabilirdi, sadece ilk ünite için değil 'astronomi' başlı̆̆ında bu proje uzun bir sürece yayılabilirdi." yanitı öğretmenlerin etkinliklerin sayı ve süre bakımında arttırılmasını istediklerini örneklendirmektedir. Ö5 ve Ö11 de yanıtlarında gökyüzü gözlemine yer verilmesinin yararlı olacağını düşündüklerini belirtmiştir. Ö5'in “2018 yılı sonu gökyüzü olayları ile alakalı etkinlikler olabilirdi." yanıtı bu durumu yansıtmaktadır. Öte yandan öğretmenler, katılımcılar arasındaki iletişimin daha güçlü olmasını ve teknolojik içerikli etkinliklerin sayıca artırılmasını istediklerini de belirtmişlerdir. Çalışma grubundaki 2 öğretmen ise bu soruyu yanıtsız birakmıştır.

\section{Projeye Tekrar Katılma İsteği}

Çalışma grubunda yer alan öğretmenlere projeye yeniden katılmayı isteyip istemedikleri sorulmuş ve cevaplarından elde edilen bulgular Tablo 7'de sunulmuştur.

Tablo 7.

Öğretmenlerin Projeye Yeniden Katılma İsteklerine İlişkin Görüşleri

\begin{tabular}{llcc}
\hline \multicolumn{1}{c}{ Kategori } & \multicolumn{1}{c}{ Katılımcı } & $\begin{array}{c}\text { Frekans } \\
\text { (f) }\end{array}$ & $\begin{array}{c}\text { Yüzde } \\
(\mathbf{\%})\end{array}$ \\
\hline $\begin{array}{l}\text { Yeniden katılmayı isteme } \\
\text { Toplam }\end{array}$ & Ö1, Ö2, Ö3, Ö4, Ö5, Ö6, Ö7, Ö8, Ö9, Ö10, Ö11 & 11 & 100.0 \\
\hline
\end{tabular}

Öğretmenlerin projeye yeniden katılma isteklerine ait bulguların yer aldı ̆̆ Tablo 7 incelendiğinde çalışma grubunda yer alan öğretmenlerin tamamının gelecek y1llarda yapılacak olan benzer bir projeye yeniden katılmak istediklerini belirttikleri görülmektedir. Elde edilen bu bulgu, proje sürecinin gerek öğretmenlere gerekse öğrencilere katkı sağladığını düşündürmektedir. 


\section{Projeye İlişkin Genel Değerlendirme}

Araştırmada öğretmenlerin projeyle ilgili genel olarak bir değerlendirme yapmaları istenmiş ve öğretmenlerin verdikleri yanitlar Şekil 5'te sunulmuştur.

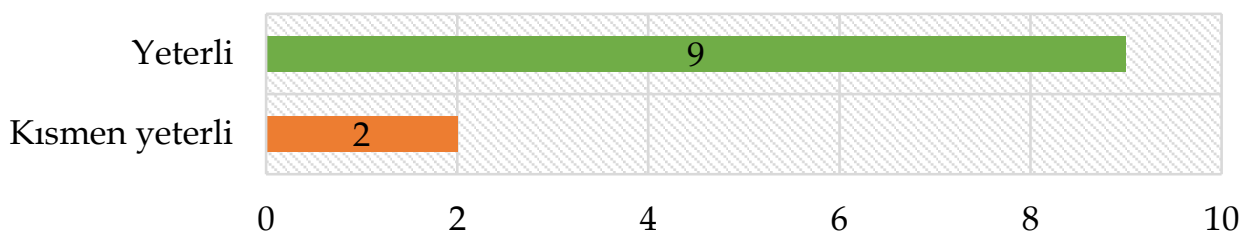

Şekil 5. Öğretmenlerin projeye ilişkin genel değerlendirmeleri

Öğretmenlerin projeye ilişkin genel değerlendirmelerine ilişkin Şekil 5'te yer alan bulgular öğretmenlerin ağırlıklı olarak projenin yeterli olduğunu (\%82) düşündüklerini göstermektedir. Ayrıca öğretmenlerin \%18'i de projenin kısmen yeterli olduğuna ilişkin görüş belirtmiştir.

\section{Tartışma, Sonuç ve Öneriler}

Araştırmaya katılan fen bilimleri öğretmenlerinin ă̆ırlıklı olarak etkinlik temelli ders işleme amacıyla eTwinning projesine katılım sağladıkları sonucuna ulaşılmıştır. Araştırma kapsamında öğretmenlerin eTwinning projesinde STEM içerikli etkinlik kullanıldığından, projenin öğrencilerde merak uyandırdığından, kalıcı ve eğlenerek öğrenmeyi sağladığından projeye katıldıkları sonucuna da erişilmiştir. STEM temelli bir öğretim ile öğrenciler öğrendikleri bilgileri anlamlandırabildiğinden öğrenme kalıcı olmaktadır (Eroğlu ve Bektaş, 2016). Mert-Cüce (2012) yaptığı bir araştırmada etkinlik temelli öğretim stratejisinin kalıcı öğrenme imkânı sunduğunu ifade etmiştir. Yine Batdı (2014) tarafından yapılan bir araştırmada etkinlik temelli öğrenme yaklaşımının öğrencilerin konuları anlamalarında etkili olması ve aynı zamanda öğrencilerde kalıcı öğrenme sağlaması sonucu bu çalışmanın sonuçları ile benzerlik göstermektedir. Camci (2012) da çalışmasında etkinliklerin öğrenmenin kalıcı olmasına katkı sağlayacağını vurgulamaktadır. Kösterelioğlu ve diğerleri (2014) yapmış oldukları bir araştırmada öğretmen adayları, etkinlikle desteklenmiş öğrenme sürecinin öğrenmeye ve kalıcılığa olumlu etkisi olduğunu ifade etmişlerdir. Projelerin kalıcı öğrenmelerin gerçekleşmesini sağladığı alanyazındaki çalışmalarda görülmektedir (Ak1ll1, 2017; Thomas, 2000; Yaşar, 2015). Alanyazındaki bu araştırmaların sonuçları yürütülen araştırmanın sonucu ile benzerlik göstermektedir. Elde edilen sonuçlar bağlamında eTwinning projeleri etkinlik temelli olduğundan, bu tip proje çalışmalarının öğrencilerde kalıcı öğrenmelere neden olabileceği düşünülmektedir.

Araştırmada öğretmenlerin mesleki yetkinliklerini artırma amacıyla eTwinning projelerine katılım sağladıkları sonucuna da ulaşılmıştır. Kampylis ve diğerleri (2012) tarafından yapılan araştırmaya katılan öğretmenler eTwinning projelerinin yaratıcı öğrenmeyi ve onlara gelişim için öğrenme fırsatları sağladığı düşüncesi bu araştırmayla benzerlik göstermektedir. Vuorikari ve diğerleri (2011) tarafından yapılan bir araştırmada da eTwinning projesi kapsamında sosyal ağların öğretmenlerin mesleki gelişimlerini destekleme ve sürdürme potansiyeline odaklanılmıştır. Vuorikari ve diğerleri (2011) araştırmaları sonucunda 28 eTwinning 
ülkesinin \%58'inde eTwinning projelerinin en azından bir ölçüde mesleki gelişim programlarının hedeflerini desteklemek için kullanılabileceği sonucuna varmışlardır. Gajek (2009) yaptı̆̆ı çalışmada eTwinning projelerinin öğretmenlerin mesleki ve kişisel gelişimine katkı sağladığını ifade etmiştir. Benzer şekilde Acar, Peker ve Küçükgençay (2020) tarafından yürütülen bir çalışmada da öğretmenlerin internet tabanlı eğitim platformlarını mesleki gelişimlerine katkı sağlamak için kullandıkları da belirlenmiştir. Araştırmadan elde edilen bu sonuç alanyazındaki çalışmalarla benzerlik taşımaktadır.

Araştırma kapsamında yer alan fen bilimleri öğretmenlerinin eTwinning projesindeki etkinliklerin verimli olduğuna, eğlenceli bir öğrenme ortamı oluşturduğuna, projenin öğretime yardımcı, ilgi çekici ve planlı olduğuna vurgu yaptıkları sonucuna ulaşılmıştır. Batdı'ya (2014) göre ders sırasında kullanılan etkinliklerin öğrencide ilgi ve istekle dersi takip etmelerini sağlamasından dolayı öğrenmeye motive etmektedir. Camci (2012) ise ders sırasında kullanılan etkinliklerin derse ilgi çekmede katkı sağlayacağını belirtmiştir. Kösterelioğlu ve diğerleri (2014) da araştırmalarında etkinlik temelli bir öğrenme ortamının ilgiyi çekme ve eğlenme imkânı verdiğinden bahsetmişlerdir. Öğrencilerin eTwinning gibi projelere katılmaları öğrenme isteklerini arttırmaktadır (Van de Craen, 2008). Oana (2008) yaptığ1 araştırmada proje çalışmalarının katılımcı öğretmen ve öğrencilerle birlikte okuldaki diğer öğretmen ve öğrencilerin de motivasyonlarını arttırdığı ve onların da bu tip projelere katılmaya istekli oldukları sonucuna ulaşmıştır. Thomas'a (2000) göre bireyin bilgiyi keşfetmesi sürecinde öğrenme sürecinde olursa öğrenme keyifli hale gelecektir, yani birey süreçte eğlenebilecektir. Bu bağlamda alanyazında yer alan çalışmalar, araştırmadan elde edilen sonuçları desteklemektedir.

Çalışma grubunda yer alan fen bilimleri öğretmenlerinin, eTwinning proje sürecindeki etkinliklerin keşfetmeyi ve kavramları somutlaştırmayı sağladığını ve kazanımlara uygun olduğunu belirttikleri sonucuna ulaşılmıştır. Proje çalışmasının amaçlarından biri de ortaya somut bir ürün koymak olduğundan (Çiftçi ve Sünbül, 2005) dolayısıyla yürütülen eTwinning proje çalışmasının soyut kavramları somutlaştırma aşamasında önemli olduğu düşünülmektedir. Bu bağlamda eTwinning projelerinin hedeflerine ulaşmasında kazanımlara uygun bir proje sürecinin oluşturulması önem taşımaktadır.

$\mathrm{Bu}$ çalışmada elde edilen sonuçlara ek olarak araştırmaya katılan fen bilimleri öğretmenleri eTwinning proje sürecindeki etkinliklerin öğrenci merkezli olduğunu, bu sayede öğrencilerin projelere etkin katılım sağladıklarını belirtmişlerdir. Etkinlik temelli öğretimin öğrenci merkezli bir yaklaşım olmasından dolayı (Asan ve Güneş, 2000) öğrenciler öğrenme eylemini kendileri gerçekleştirmekte ve yaparak yaşayarak öğrenmektedirler (Mert-Cüce, 2012). Kösterelioğlu ve diğerleri (2014) yapmış oldukları bir araştırmada öğretmen adayları, etkinliklerle desteklenmiş öğrenme sürecinin kendilerini pasiflikten kurtardı̆̆ını ifade etmişlerdir. eTwinning projelerinde de öğretmenin rehberlik yaptığı öğrenciler projenin merkezinde yer alır ve sürece etkin katılım sağlayarak öğrenmelerini gerçekleştirmektedir. Bu nedenle öğrencilere nasıl öğreneceği öğretilmelidir ve öğrenme sürecinde birey zevk almalıdır (Ersoy, 2006). Bu araştırmada da katılımcı öğretmenler, eTwinning projesinde öğrencilerin katılımda istekli olduklarını belirtmişlerdir. Bu bağlamda öğrencilerin katılımda istekli olmasından dolayı öğrenmelerinin de etkin bir şekilde gerçekleştiği 
düşünülmektedir. Öğretmenler, öğrencilerin derste aktif ve etkin bir rol almalarını sağlamasıyla onların dersi sevmelerini ve derse yönelik olumlu tutum geliştirmelerini sağlayabilmektedir (Batd1, 2014). Bu araştırmanın sonuçları bağlamında eTwinning projelerinde de öğrencinin merkeze alınması sebebiyle öğrencilerin eTwinning projelerine ve projenin yapıldığ1 derslere ilişkin olumlu tutum geliştirebilecekleri düşünülmektedir.

Araştırmada çalışmaya katılan fen bilimleri öğretmenlerinin eTwinning proje sürecine katılan öğrencilerinin ilgilerinin artmasını, eğlenerek öğrenmelerini ve keşfetmeye yönelmelerini projenin öğrencilere katkısı olarak düşündükleri sonucuna ulaşılmıştır. Batdı (2014) araştırmasında etkinlik temelli öğrenme yaklaşımları ile öğrencilerin dersleri daha çok sevdiğini ve derse yönelik ilgilerinin artığını belirtmektedir. Elde edilen bu sonuç yapılan araştırmanın sonucu ile benzerlik göstermektedir. Velea (2011) tarafından yürütülen eTwinning araştırmasında da öğrenciler bilgisayarla çalıştıkları işbirlikli projeler için büyük ilgi duyduklarını ifade etmişlerdir.

$\mathrm{Bu}$ çalışma kapsamında araştırmaya katılan fen bilimleri öğretmenlerinin, öğrencilerin etkinliklere katılımının artması için etkinliklerin türünün ve sayısının artırılması, proje süresinin uzatılması merak uyandırmaya yönelik etkinlikler oluşturulması ve ilginç etkinliklere yer verilmesi gerektiğini düşündükleri sonucuna da ulaşılmıştır. Mert-Cüce'ye (2012) göre öğrencinin merak duygusunu uyandırmak etkinlik temelli öğrenmenin en önemli üstünlüğüdür. Proje çalışmaları ile öğrenme isteği olan ve merak duygusu olan bireylerin yetiştirilmesi hedeflenmektedir (Bozdemir, 2018). eTwinning projelerinin de etkinlik temelli gerçekleştirilmesinden dolayı öğretmenler öğrencilerin etkinliklere katılımının artması için merak uyandırmaya yönelik etkinlikler oluşturmak gerektiğini ifade etmişlerdir.

Araştırmadaki fen bilimleri öğretmenlerinin katıldıkları eTwinning projesinde sürenin kısıtlı olması, katılımcı öğretmenler arasındaki iş birliğinin istenilen düzeyde olmaması, etkinliklerin sayıca az olması, katılımcılar arasında iletişim eksikliğinin olması gibi eksik yanları olduğunu düşündükleri sonucuna ulaşılmıştır. Öğretim programında ilgili sınıflardaki astronomi konuları için ayrılan ve araştırmanın sınırlılığı olan 5 haftalık sürecin araştırmaya katılan öğretmenlerin yanıtlarını etkilediği görülmektedir. Yapılan bu çalışmayla benzer olarak Özgan ve Turan (2010) tarafından yapılan araştırmada etkinlik temelli yapılandırmacı yaklaşım uygulama sürecinde öğretmenler zaman sıkıntısı ve iş birliği eksikliği sorunlarla karşılaştıklarından bahsetmişlerdir. Yine bu araştırmadaki sonuca benzer olarak derslerde etkinliklerin uygulanması sürecinde zaman sorunundan bahsedilen araştırmalara da alanyazında rastlanılmaktadır (Mert-Cüce, 2012; Siew, Amir ve Chong, 2015). Etkinlikle desteklenmiş öğrenme süreci bireyler arasındaki iletişimi arttırmaktadır (Kösterelioğlu vd., 2014). Okul iş birliği, iyi bilinen bir kavramdır ve dünyadaki birçok okulda uygulanmaktadır (Vuorikari vd., 2011). Çünkü iş birliği okulun kurumsal gelişimi için önemlidir (Velea, 2011). Bununla birlikte, eTwinning projeleri yeniliği, yaygın ve dağınık uygulamaları sağlam bir çerçeve altında toplamaktadır. Bu sayede uygulamaların paylaşılması ve daha fazla ağ oluşturma için daha iyi imkânlar elde edilmektedir (Vuorikari vd., 2011). İzgi-Onbaş1lı (2020) da araştırmasında eTwinning projelerinin bilişim teknolojileri aracılığıyla okullar arasında ortaklıklar kurularak iş birliği içerisinde çeşitli çalışmalar gerçekleştirme 
konusunda öğretmenlere imkân sağladığını belirtmektedir. Bu araştırmaya katılan fen bilimleri öğretmenleri de katılımcılar arasındaki iletişimin daha güçlü olması gerektiğini belirtmişlerdir. Yapılacak eTwinning projelerinin sayısının arttırılması ile paydaşlar arasındaki iletişim eksikliğinin giderileceği düşünülmektedir.

Araştırmaya katılan öğretmenler projenin eksik yanlarını göz önünde bulundurarak projeyle ilgili etkinlik süresinin uzatılması, teknoloji destekli etkinlik sayısının artırılması ve konuyla ilgili öğrencilerin gözlem yapabilmesi gibi değişiklikler yapılmasını istediklerinden bahsetmişlerdir. Bu durum araştırmanın bir sınırlılığ1 olan etkinlik sayısının, araştırmaya katılan öğretmenlerin yanıtlarına etki ettiğini göstermektedir. Velea (2011) da eTwinning projelerinin temelinde öğretmenlerin öğrencilerinin öğrenme faaliyetlerini çeşitlendirmenin, fikirlerini ve deneyimlerini diğer Avrupalı meslektaşları ile paylaşmanın, eğitimdeki kültürel sınırların üstesinden gelerek öğretim yöntemlerini sürekli yenilemenin yer aldığını vurgulamaktadir.

Son olarak araştırmaya katılan fen bilimleri öğretmenlerinin tamamının gelecek y1llarda yapılacak olan benzer bir projeye yeniden katılmak istediklerini belirttikleri sonucuna ulaşılmıştır. Bu durumun oluşmasında proje sürecinin gerek öğretmenlere gerekse öğrencilere çeşitli katkılar sağlamasının etkili olduğu düşündürmektedir.

Çalışmaya katılan fen bilimleri öğretmenleri, proje süresinin uzatılması gerektiğini belirtmişlerdir. $\mathrm{Bu}$ sonuç doğrultusunda eTwinning projelerinin sürelerinin yapılan iyi planlamalar sonrasında proje ortaklarının avantajları ve dezavantajları düşünülerek düzenlenmesi önerilmektedir.

eTwinning projelerinin en önemli ayağı olan öğretmenlerin deneyimlerini arttırmak için onların mesleki yetkinliklerini arttıracak eTwinning projelerinin tasarlanması ve eTwinning projeleri konusunda öğretmenlere hizmet içi eğitimlerin verilmesi önerilmektedir. Araştırmaya katılan öğretmenler, eTwinning projelerine katılımın ve etkinliklerin arttırılması gerektiğini düşünmektedir. $\mathrm{Bu}$ sonuç bağlamında proje ortaklarının arttırılması ve projelere daha çok öğrencinin entegre edilmesi önerilmektedir. Bu süreçte öğretmenlere ve öğrencilere materyal ve teknik destek sağlanmalıdır. Ayrıca eTwinning projelerinde yapılan etkinliklerin daha fazla beceriyi ortaya çıkarması amaçlanarak yürütülen proje sayısı arttırılmalıdır.

Günümüzde doğru bilgiye ulaşabilmek için bireylerin 21. yüzyıl becerilerine sahip olması gerekmektedir. Disiplinlerarası ve uygulamaya yönelik bir yaklaşıma sahip fen, teknoloji, mühendislik ve matematik alanlarının birbirleriyle bütünleştirilmesi sayesinde STEM eğitimiyle bireylere 21. yüzyıl becerileri kazandırılabilir (Aydın, Saka ve Guzey, 2017). Bu bağlamda eTwinning projelerindeki etkinliklerin STEM içerikli olmasıyla bireylere 21. yüzyıl becerilerini kazandırılabilir veya bireylerin bu becerileri geliştirilebilir. Bu sürecin etkililiğinin incelenmesi amacıyla araştırmacılara deneysel çalışmalar yürütmeleri önerilmektedir. Çalışma grubuna ait demografik özellikler de dikkate alınarak verilerin farklılaşıp farklılaşmadığına ilişkin bilgiler tespit edilebilir.

eTwinning projelerinin içeriği genişletilebilir. eTwinning projelerinin öğretime yardımcı, kazanımlarla ilişkili, günlük yaşam problemlerini çözebilecek nitelikte olması ve projelerde ilgi çekici, merak uyandırıcı etkinliklerin yer alması önerilmektedir. Dolayısıyla öğrenme-öğretme ortamının da öğrencilerin ilgi, yetenek ve ihtiyaçlarına göre tasarlanması gerektiği düşünülmektedir. 
eTwinning projelerinde okul ortakları arasında hem öğretmenlerin hem de öğrencilerin iş birliği ve iletişimi önemli olduğundan sosyal öğrenme, paylaşım, iş birliği, sorumluluk duygularını pekiştirecek ve iletişim becerilerinin geliştirilebileceği proje ve etkinliklerin tasarlanması önerilmektedir.

eTwinning projeleri etkinlik temelli öğrenme yaklaşımına göre gerçekleştiğinden öğretmenlerin bu yaklaşımın temel prensipleri hakkında yeterli bilgi birikimine sahip olmaları gerekmektedir. Bu konu hakkında öğretmenlere MEB tarafından yüz yüze ya da uzaktan hizmetiçi eğitimler verilebilir. Ayrıca öğretmenler için zengin içerikli kılavuz kaynaklar oluşturulabilir.

Yapılabilecek farklı çalışmalarda çalışma grubu herhangi bir eğitime katılmamış öğretmenlerden ve herhangi bir projeye dahil olmamış öğrencilerden oluşturularak eğitimlerde sürecin bireylere sağladığı katkının ve süreçte yaşanılan sorunların tespit edilmesine ilişkin eylem araştırmaları yürütülebilir. Farklı desenlerde nitel çalışmalar yürütülerek sürece ve uygulamalara ilişkin zengin ve derinlemesine bilgiler elde edilebilir. Bunların yanı sıra nicel ve nitel bulguları birbiriyle destekleyerek karma desenli araştırmaların yürütülmesi de araştırmacılara önerilmektedir.

\section{Kaynakça}

AB Eğitim, Öğretim, Gençlik ve Spor Programı (2020). eTwinning nedir? https:/ / www.etwinning.net/tr/pub/index.htm adresinden 17.08.2020 tarihinde erişim sağlanmıştır.

Acar, S., Peker, B. ve Küçükgençay, N. (2020). Çeşitli branşlardaki ortaokul öğretmenlerinin online eğitim platformları hakkındaki görüşleri. International Journal of Social, Humanities and Administrative Sciences, 6(27), 901-925. https:/ / doi.org/10.31589/JOSHAS.347

Açıkgöz, K. Ü. (2002). Aktiföğrenme. İzmir: Eğitim Dünyası Yayınları.

Akdemir, A. S. (2017). eTwinning in language learning: The perspectives of successful teachers. Journal of Education and Practice, 8(10), 182-190.

Akıllı, C. (2017). Proje döngüsü yönetim aşamaları açısından öğretmen ve yöneticilerin hazırladıkları ve yürüttükleri eğitim projelerinde karşılaşılan sorunlar (Elazığ ili örneği). ((Yayımlanmamış Yüksek Lisans Tezi)), Furat Üniversitesi Eğitim Bilimleri Enstitüsü, Elazı̆̆.

Akınc1, B., Uzun, N. ve Kışoğlu, M. (2015). Fen bilimleri öğretmenlerinin meslekte karşılaştıkları problemler ve fen öğretiminde yaşadıkları zorluklar. International Journal of Human Sciences, 12(1), 1189-1215. https://doi.org/10.14687/ijhs.v12i1.3188

Aksoy, H. H. (2003). Eğitim kurumlarında teknoloji kullanımı ve etkilerine ilişkin bir çözümleme. Eğitim Bilim Toplum Dergisi, 1(4), 4-23.

Arı, K., Çavuş, H. ve Sağlık, N. (2010). İlköğretim 6. sınıflarda geometrik kavramların öğretiminde etkinlik temelli öğrenimin öğrenci başarısına etkisi. Pamukkale Üniversitesi Ĕ̆itim Fakültesi Dergisi, 27, 99-112.

Asan, A. ve Güneş, G. (2000). Oluşturmacı öğrenme yaklaşımına göre hazırlanmış örnek bir ünite etkinliği. Millî Ĕ̆itim Dergisi, 147, 50-53.

Aydın, G., Saka, M. ve Guzey, S. (2017). 4-8. sınıf öğrencilerinin fen, teknoloji, mühendislik, matematik (STEM=FETEMM) tutumlarının incelenmesi. Mersin 
Üniversitesi Eğitim Fakültesi Dergisi, 13(2) 787-802.

https:/ / doi.org/10.17860/mersinefd.290319

Aydın, M., Laçin, S. ve Keskin, İ. (2018). Ortaöğretim matematik dersi öğretim programının uygulanmasına yönelik öğretmen görüşleri. International e-Journal of Educational Studies, 2(3), 1-11. https:/ / doi.org/10.31458/iejes.413967

Balba ğ, M. Z., Leblebicier, K., Karaer, G., Sarıkahya, E. ve Erkan, Ö. (2016). Türkiye' de fen eğitimi ve öğretimi sorunları. Eğitim ve Öğretim Araştırmaları Dergisi, 5(2), 12-23.

Başdaş, E. (2007). Illköğretim fen eğitiminde basit malzemelerle yapılan fen aktivitelerinin bilimsel süreç becerilerine, akademik başarrya ve motivasyona etkisi. ((Yayımlanmamış Yüksek Lisans Tezi)), Celal Bayar Üniversitesi Fen Bilimleri Enstitüsü, Manisa.

Batdı, V. (2014). Etkinlik temelli öğrenme yaklaşımının akademik başarıya etkisi (Meta-analitik ve tematik bir çalışma). E-International Journal of Educational Research, 5(3), 39-55. https:/ / doi.org/10.19160/e-ijer.12976

Bozdağ, Ç. (2017). Almanya ve Türkiye' de okullarda teknoloji entegrasyonu: eTwinning örneği üzerine karşılaştırmalı bir inceleme. Ege Eğitim Teknolojileri Dergisi, 1(1), 42-64.

Bozdemir, E. (2018). TÜBİTAK bilim fuarlarında yapılan projelerin öğrenciler üzerindeki etkililiğinin değerlendirilmesi. ((Yayımlanmamış Yüksek Lisans Tezi)), Çanakkale Onsekiz Mart Üniversitesi Eğitim Bilimleri Enstitüsü, Çanakkale.

Buluş-Kırıkkaya, E. ve Yıldırım, İ. (2019). Eğitim portalları hakkında fen bilimleri öğretmenleri ne düşünüyor? Uluslararası Bilimsel Araştırmalar Dergisi, 4(2), 222235. https:// doi.org/10.21733/ibad.531997

Camci, F. (2012). Aktif öğrenmeye dayalı etkinlik temelli öğretimin öğrencilerin akademik becerilerine ve öğrenme sürecine etkisi. ((Yayımlanmamış Yüksek Lisans Tezi)), Adıyaman Üniversitesi Fen Bilimleri Enstitüsü, Adıyaman.

Camilleri, R. A. (2016). Global education and intercultural awareness in eTwinning. Cogent Education, 3(1). https:/ / doi.org/10.1080/2331186X.2016.1210489

Coşkun, E. (2005). İlköğretim dördüncü ve beşinci sinıf öğretmen ve öğrencilerinin yeni Türkçe dersi öğretim programıyla ilgili görüşleri üzerine nitel bir araştırma. Kuram ve Uygulamada Eğitim Bilimleri Dergisi, 5(2), 421-476.

Crişan, G. I. (2013). The impact of teachers' participation in eTwinning on their teaching and training. Acta Didactica Napocensia, 6(4), 19-28.

Çetin, Ö., Çakıroğlu, M., Bayılmış, C. ve Ekiz, H. (2004). Teknolojik gelişme için eğitimin önemi ve internet destekli öğretimin eğitimdeki yeri. The Turkish Online Journal of Educational Technology, 3(3), 144-147.

Çiftçi, S. ve Sünbül, A. M. (2005, Kasım). Proje Tabanlı Öğrenme Düşüncesinin Oluşumu ve Gelişimi. I. Ulusal Fen ve Teknoloji Eğitiminde Çă̆daş Yaklaşımlar Sempozyumu, Ankara.

Doğan, Y. (2010). Fen ve teknoloji dersi programının uygulanması sürecinde karşılaşılan sorunlar. Yüzüncü Yıl Üniversitesi Eğitim Fakültesi Dergisi, 7(1), 86106 
Doolittle, P. E. (2014). Complex constructivism: A theoretical model of complexity and cognition. International Journal of teaching and learning in higher education, 26(3), 485-498.

Eroğlu, S. ve Bektaş, O. (2016). STEM eğitimi almış fen bilimleri öğretmenlerinin stem temelli ders etkinlikleri hakkındaki görüşleri. Ĕ̆itimde Nitel Araştırmalar Dergisi, 4(3), 43-67.

Ersoy, A. F. (2016). Fenomenoloji. A. Saban ve A. Ersoy (Ed.), Eğitimde nitel araştırma desenleri (s. 53-106) içinde. Ankara: Anı Yayıncılık.

Ersoy, Y. (2006). Innovations in mathematics curricula of elementary schools-I: Objective, content and acquisition. Elementary Education Online, 5(1), 30-44.

Fat, S. (2012, April). The impact study of eTwinning projects in Romania. Paper presented at the 8th International Scientific Conference eLearning and Software for Education.

Gajek, E. (2009). Online course for teachers: How to participate in the eTwinning programme? In e-Twinning - A Way to Education of the Future (p. 152-165). Warsaw: Foundation for the Development of the Education System,

Gajek, E. (2012). Constructionism in action within European eTwinning projects. In Computer-enhanced and mobile-assisted language learning: Emerging issues and trends (pp. 116-136). IGI Global. https:/ / doi.org/10.4018/978-1-61350-0651.ch006

Gülcü, A., Solak, M., Aydın, S. ve Koçak, Ö. (2013). İlköğretimde görev yapan branş öğretmenlerinin eğitimde teknoloji kullanımına ilişkin görüşleri. Electronic Turkish Studies, 8(6), 195-213. https://doi.org/10.7827/TurkishStudies.4899

Gürbüz, R., Çatlığlu, H. Birgin, O., and Erdem, E. (2010). An investigation of fifth grade students' conceptual development of probability through activity based instruction: A quasi-experimental study. Educational Sciences: Theory E Practice, 10(2), 1021-1069.

Holmes, B. (2012). Online learning communities for school teachers' continuous professional development: The cognitive, social and teaching aspects of an eTwinning Learning Event (Doctoral dissertation), Lancaster University. https:/ /doi.org/10.1007/978-3-319-01940-6_10

Ishii, D., K. (2003). Constructivist views of learning in science and mathematics. ERIC Clearinghouse for Science Mathematics and Environmental Education Columbus OH. ERIC Digest, ED482722.

İzgi-Onbaş1lı, Ü. (2020). The effects of science teaching practice supported with web 2.0 tools on prospective elementary school teachers' self-efficacy beliefs. International Journal of Progressive Education, 16(2), 91-110. https:/ / doi.org/10.29329/ijpe.2020.241.7

Kampylis, P., Bocconi, S., and Punie, Y. (2012, August). Fostering innovative pedagogical practices through online networks: The case of eTwinning. In Proceedings of the SQM/INSPIRE 2012 conference, Tampere, Finland.

Karacaoğlu, Ö. C. ve Acar, E. (2010). Yenilenen programların uygulanmasında öğretmenlerin karşılaştı̆̆ı sorunlar. Yüzüncü Yıl Üniversitesi Ĕ̆itim Fakültesi Dergisi, 7(1), 45-58. 
Karaman, P. ve Karaman, A. (2016). Fen bilimleri öğretmenlerinin yenilenen fen bilimleri öğretim programına yönelik görüşleri. Erzincan Üniversitesi Eğitim Fakültesi Dergisi, 18(1), 243-269. https:/ / doi.org/10.17556/jef.65883

Koç, A. ve Böyük, U. (2012). Basit malzemelerle yapılan deneylerin fene yönelik tutuma etkisi. Türk Fen Eğitimi Dergisi, 9(4), 102-118.

Konstantinidis, A. (2012). Implementing learning-oriented assessment in an eTwinning online course for Greek teachers. Journal of Online Learning and Teaching, 8(1), 45-62.

Kösterelioğlu, İ., Bayar, A. ve Akın-Kösterelioğlu, M. (2014). Öğretmen eğitiminde etkinlik temelli öğrenme süreci: Bir durum araştırması. Electronic Turkish Studies, 9(2), 1035-1047. https:/ / doi.org/10.7827/TurkishStudies.6406

Kurtdede-Fidan, N. (2015). Sınıf öğretmeni adaylarının yapılandırmacı kurama ilişkin algılarının belirlenmesi: Fenomenografik bir çalışma. Celal Bayar Üniversitesi Sosyal Bilimler Dergisi, 13(4), 263-282. https:/ / doi.org/10.18026/cbusos.76371

Küçüköner, Y. (2011). 2005 fen ve teknoloji dersi öğretim programının uygulanmasında karşılaşılan sorunlar ve öğretmen gözüyle çözüm önerileri. Erzincan Üniversitesi Eğitim Fakültesi Dergisi, 13(2), 11-37.

Kyriacou, C. (1992). Active learning in secondary school mathematics. British Educational Research Journal, 18(3), 309-318. https:/ / doi.org/10.1080/0141192920180308

Mayring, P. (2000). Nitel sosyal araştırmaya giriş. (Çev. A. Gümüş ve M. S. Durgun). Adana: Baki Kitabevi.

Mert-Cüce, A. P. (2012). Etkinlik temelli matematik öğretimi yapılan sinıf ortamından yansımalar: Aksiyon araştırması. (Yayımlanmamış Yüksek Lisans Tezi), Karadeniz Teknik Üniversitesi Eğitim Bilimleri Enstitüsü, Trabzon.

Miles, M, B., and Huberman, A. M. (1994). Qualitative data analysis: An expanded sourcebook. Thousand Oaks, CA: Sage.

Moura, A. (2014). Apps e podcasts para a aula invertida: Um projeto eTwinning em lingua estrangeira no ensino basico. Atas do, 2, 345-351.

Oana, G. (2008). eTwinning in 2008. Elearning. Romania. Bucureşti: TEHNE-Centrul pentru Dezvoltare şi Inovare în Educație. Available online: http://www. elearning. ro.

Özgan, H. ve Turan, E., (2010). Yapılandırmacı yaklaşımın uygulanmasında karşılaşılan sorunların çözümüne yönelik öğretmenlerin yöneticilerden beklentileri. 9. Ulusal Sını Öğretmenliği Ĕ̆itimi Sempozyumu, Elazı̆̆.

Papadakis, S., and Kalogiannakis, M. (2010, July). eTwinning in the early childhood as starting line of innovative practices for the didactic of natural sciences. In HSci2010 7th International Conference Hands-on Science Bridging the Science and Society Gap. Greece: University of Crete.

Pekdağ, B. (2005). Fen eğitiminde bilgi ve iletişim teknolojileri. Balıkesir Üniversitesi Fen Bilimleri Enstitüsü Dergisi, 7(2), 86-94.

Sadi, Ö. ve Çakıroğlu, J. (2011). Effects of hands-on activity enriched instruction on students' achievement and attitudes towards science. Journal of Baltic Science Education, 10(2), 87-97. 
Saunders, W. L. (1992). The constructivist perspective: Implications and teaching strategies for science. School Science Mathematics, 92(3), 136-141. https:/ / doi.org/10.1111/j.1949-8594.1992.tb12159.x

Siew, N. M., Amir, N., and Chong, C. L. (2015). The perceptions of pre-service and inservice teachers regarding a project-based STEM approach to teaching science. Springer Plus, 4(8), 1-20. https:/ / doi.org/10.1186/2193-1801-4-8

Suzuki, K., and Harnisch, D. L. (1995, April). Measuring cognitive complexity: An analysis of performance-based assessment in mathematics. Paper presented at the 1995 Annual Meeting of the American Educational Research Association, San Francisco, CA.

Şahin, Ö. (2012). MEB Vitamin ilköğretim portalı hakkındaki öğretmen görüşlerinin ve ögrenci tutumlarının incelenmesi. (Yayımlanmamış Yüksek Lisans Tezi), Gaziantep Üniversitesi Sosyal Bilimler Enstitüsü, Gaziantep.

Thomas, J. W. (2000). Managing project-based learning: Principles from the field. Paper presented at the Annual Meeting of the American Educational Research Association, New Orleans.

Tuncer, M. ve Taşpınar M. (2007). Sanal eğitim-öğretim ve geleceği. Elektronik Sosyal Bilimler Dergisi, 6(20), 112-133.

Türk Eğitim Derneği [TED]. (2009). Öğretmen yeterlikleri. Ankara: Türk Eğitim Derneği Yayınları.

Uğurel, I. ve Bukova-Güzel, E. (2010). Matematiksel öğrenme etkinlikleri üzerine bir araştırma ve kavramsal bir çerçeve önerisi. Hacettepe Üniversitesi Eğitim Fakültesi Dergisi, 39, 333-347.

Valles, M. (2017). Percepción del alumnado con respecto al desarrollo de la competencia intercultural en el proyecto telecolaborativo eTwinning "Preparados para un Erasmus!/Prêts pour un Erasmus!". Tendencias Pedagógicas, 30, 245-266. https:// doi.org/10.15366/tp2017.30.014

Van de Craen, P. (2008). Aventuri pe tărâmuri lingvistice şi culturale. European Schoolnet.

Velea, S. (2011). ICT in education: Responsible use or a fashionable practice. The impact of eTwinning action on the education process. In ICVL. Proceedings of the 6th International Conference on Virtual Learning. Bucharest: University of Bucharest Publishing House.

Vuorikari, R., Berlanga, A., Cachia, R., Cao, Y., Fetter, S., Gilleran, A., Klamma, R., Punie, Y., Scimeca, S., and Sloep, P. (2011, December). ICT-based school collaboration, teachers' networks and their opportunities for teachers' professional development-a case study on eTwinning. In International conference on web-based learning (p. 112-121). Berlin, Heidelberg: Springer.

https://doi.org/10.1007/978-3-642-25813-8_12

Yamiç, Y. (2019). Fen bilimleri öğretmenlerinin proje hazırlama konusundaki görüşlerinin belirlenmesi. (Yayımlanmamış Yüksek Lisans Tezi), Trabzon Üniversitesi Lisansüstü Eğitim Enstitüsü, Trabzon.

Yanpar-Yelken, T. (2009). Öğretmen adaylarının portfolyoları üzerinde grup olarak yaratıcılık temelli materyal geliştirmenin etkileri. Ĕğitim ve Bilim, 34(153), 83-98. 
Yaşar, M. (2015). Coğrafya öğretmenlerinin proje hazırlama ve yönetme sürecine ilişkin görüşleri. (Yayımlanmamış Yüksek Lisans Tezi), Gazi Üniversitesi Eğitim Bilimleri Enstitüsü, Ankara.

Yıldırım, A. ve Şimşek, H. (2008). Sosyal bilimlerde nitel araştırma yöntemleri. Ankara: Seçkin Yayınevi.

\section{Summary}

\section{Introduction}

The changes that happened at every stage of education have enabled teachers to be integrated into this process. Including activities that students will actively participate in the learning-teaching process has made it necessary for teachers to create their own activities. Various project studies are carried out to share these activities and to carry out joint activities with students in different schools. In this context, an eTwinning education platform has been established to increase teacher and student cooperation, communicate and develop projects among schools in Europe. Each teacher in the project participates in the activities with their own students. At the same time, teachers and students can share images of the activities related to the project, communicate with each other and present their different works to other participants. In this process, students play a more active role in the classroom. Teachers emerge as the most important factor in eTwinning projects as in lessons. Teachers should create a rich learning environment in the lessons and have some competencies, and they have similar responsibilities in projects such as eTwinning. Teachers are of great importance in the project process as they will guide the students with their competencies. Although eTwinning projects have been popular in recent years, it is seen that the number of studies on the opinions of teachers regarding the projects are inadequate. In the present research, opinions of science teachers who participated in eTwinning projects about their experiences in the process of project were examined.

\section{Method}

This research is a phenomenological study designed in accordance with qualitative research method. In phenomenological studies, it is aimed to determine individuals' view of the event through their views on the facts (Ersoy, 2016; Mayring, 2000). In this research, it was focused on the opinions of science teachers about the eTwinning Project in which they participated. In the formation of the study group, criterion sampling which is a type of purposeful sampling was used. In the criterion sampling, the participants who provide various criteria, which were predefined, participate in the research process (Yıldırım and Şimşek, 2008). In this study, being a science teacher, participating in the eTwinning project and performing the activities specified in the process were accepted as the main criteria. The study group of the current research consists of 11 science teachers who worked in different cities of Turkey in the 20182019 academic year. The teachers in the study group were asked to participate in the project study that was prepared for the activity-based teaching of astronomy topics carried out through the eTwinning platform. Within the five-week period, teachers carried out the activities related to project in the eTwinning platform in their classrooms, and they shared their opinions and visuals about the activities with the 
other colleagues who participated in the project. In addition, they also shared the activities that they designed themselves with other teachers who participated in projects on the digital platform. At the end of the process, the project was completed when teachers organized an exhibition in order to present their students' activities and the products created at their schools. As the data collection tool in the research, open ended question form was used. There are nine questions in the form. With the questions in the form, the following questions were asked to teacher:

- Their reasons to join the project,

- Their opinions about the project,

- Their opinions about contribution of the project to students,

- Their opinions about their students' participation in the project,

- Their opinions related to the activities that can be done to increase students' participation,

- Their opinions on deficiencies in the project process,

- Their opinions about the changes they want to be made about the project,

- Their requests to rejoin the project,

- Their general evaluations about the project.

The content analysis was used in the analysis of data. The data obtained were supported via opinions of teachers.

\section{Results}

As a result of the research, it was determined that teachers participated in these project studies in order to teach activity-based courses and contribute to their professional development. On the other hand, it is also a result of the activities that made the students raise curiosity; therefore, they actively participated in the process, learned by having fun and embodied abstract concepts. In the research, it was determined that the teachers thought that contributions of eTwinning project to students were that it increased their interest and tendency to explore. The teachers made suggestions such as longer time period for the project is needed, more activities should be involved and the communication should be stronger between colleagues in the process. The results show that eTwinning projects have made many contributions to teachers and students.

\section{Discussion}

With an activity-based teaching, students' knowledge becomes more permanent (Batd1, 2014; Camci, 2012; Eroğlu and Bektaş, 2016; Kösterelioğlu et al., 2014; MertCüce, 2012). Similarly, projects also provide students with permanent learning (Ak1ll1, 2017; Thomas, 2000; Yaşar, 2015). The results of these studies in the literature are similar to the results of the present study. In this context, since eTwinning projects are activity-based, it is thought that this type of project work may lead to permanent learning in students.

In this context of results obtained in this research, eTwinning projects are thought to contribute to the professional development of teachers. When the literature is reviewed, the studies conducted (Gajek, 2009; Kampylis et al., 2012; Vuorikari et al., 2011) support this idea. An activity-based learning environment increases students' interest (Batd1, 2014; Camci, 2012; Kösterelioğlu et al., 2014). Participation of students in any project Oana (2008) and eTwinning projects (Van de Craen, 2008) increases their 
desire to learn. According to Thomas (2008), learning will be enjoyable if the individual is in the process of learning while discovering knowledge. That is, the individual will be able to have fun in the process. In this context, the studies in the literature support the results obtained from the research. In addition, the results show that the activities in the eTwinning project process enable to discover and embody abstract concepts. Based on the results of the research, since the student is taken to the center in eTwinning projects, it is believed that students can develop a positive attitude towards eTwinning projects and the courses in which the project is carried out.

According to Mert-Cüce (2012), stimulating the curiosity of the student is the most important advantage of activity-based learning. With the project, the aim is to raise of individuals who have a desire to learn and a sense of curiosity (Bozdemir, 2018). Due to the fact that eTwinning projects are carried out on an activity basis, the teachers stated that it is necessary to create activities the aim of which is to arouse curiosity in order to increase the participation of the students in the activities. Teachers have time-related problems while applying activities in lessons (Mert-Cüce, 2012; Özgan and Turan, 2010; Siew et al., 2015). The results stated in the literature are similar to result of this research. The result obtained showed that the project process had made many contributions to both teachers and students.

\section{Pedagogical Implications}

The eTwinning projects will increase teachers' professional competencies. A successful project process will take place when the project duration, the number of activities, the order of the environment and the cooperation with the project partners are taken into consideration in the works to be carried out by the teachers and by the researchers. Thus, students' interest in activities and projects will increase and their curiosity, $21^{\text {st }}$ century skills and social learning will develop in this process.

\section{Araştırmanın Etik Taahhüt Metni}

Yapılan bu çalışmada bilimsel, etik ve alıntı kurallarına uyulduğu; toplanan veriler üzerinde herhangi bir tahrifatın yapılmadığı, karşılaşılacak tüm etik ihlallerde "Cumhuriyet Uluslararası Eğitim Dergisi ve Editörünün" hiçbir sorumluluğunun olmadığ1, tüm sorumluluğun Sorumlu Yazara ait olduğu ve bu çalışmanın herhangi başka bir akademik yayın ortamına değerlendirme için gönderilmemiş olduğu sorumlu yazar tarafından taahhüt edilmiştir.

\section{Authors' Biodata/Yazar Bilgileri}

Ragıp ÇAVUŞ Sakarya Üniversitesi Eğitim Bilimleri Enstitüsü Matematik ve Fen Bilimleri Eğitimi Bölümünde doktora öğrencisidir. Aynı zamanda Millî Eğitim Bakanlığına bağlı bir ortaokulda fen bilimleri öğretmeni olarak görev yapmaktadır. Yazar STEM, sosyobilimsel konular, okul dışı öğrenme ortamları ve öğretim etkinlikleri ile ilgili konularda çalışmalar yürütmektedir.

Ragıp Çavuş is a PhD student at Sakarya University, Institute of Educational Sciences, Department of Mathematics and Science Education. He also works as a science teacher at a secondary school affiliated to the Ministry of National Education. The author conducts studies on STEM, socioscientific issues, out-of-school learning environments and teaching activities. 
Muhammed Doğukan BALÇIN Marmara Üniversitesi Eğitim Bilimleri Enstitüsü Matematik ve Fen Bilimleri Eğitimi Bölümünde doktora öğrencisidir. Aynı zamanda Millî Eğitim Bakanlığına bağlı bir ortaokulda fen bilimleri öğretmeni olarak görev yapmaktadır. Yazar STEM, teknolojik pedagojik alan bilgisi, öğrencilerin mühendis ve bilim insanı algısı, okul dışı öğrenme ortamları ve öğretim etkinlikleri ile ilgili konularda çalışmalar yürütmektedir.

Muhammed Doğukan Balçın is a PhD student at Marmara University, Institute of Educational Sciences, Department of Mathematics and Science Education. He also works as a science teacher at a secondary school affiliated to the Ministry of National Education. The author conducts studies on STEM, technological pedagogical content knowledge, engineer and scientist perception of students, out-of-school learning environments and teaching activities.

Muhammet Mustafa YILMAZ Balıkesir Şehit Prof. Dr. İlhan Varank Bilim ve Sanat Merkezinde fen bilimleri öğretmeni olarak görev yapmaktadır. Yazar kavram öğretimi, yapılandırmacı öğrenme ortamları ve öğretim etkinlikleri konularında çalışmalar yapmaktadır.

Muhammet Mustafa Y1lmaz is working as a science teacher at the Martyr Prof. Dr. Illhan Varank Science and Art Center in Balıkesir. The author works on concept teaching, constructivist learning environments and teaching activities. 